\title{
Hannah Arendt: pensar la política después de Auschwitz; pero, ¿cómo?
}

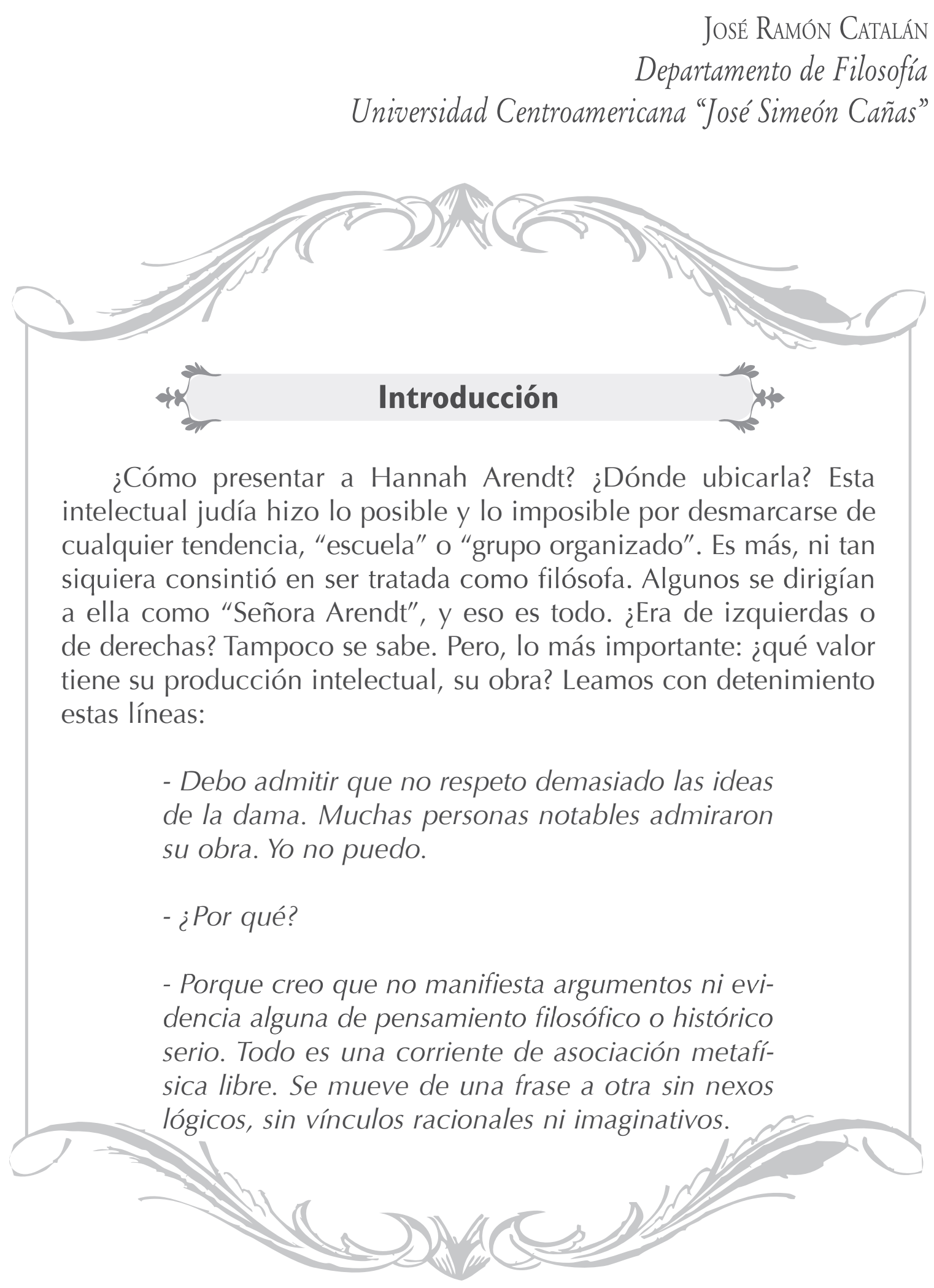


El entrevistado recuerda la polémica de Arendt con Scholem a propósito de Eichmann en Jerusalén:

- Sí. Yo no estoy dispuesto a tragarme esa idea suya de la banalidad del mal. Me parece falsa. Los nazis no eran "banales". Eichmann creía profundamente en lo que hacía; era, él lo admitió, eje de su existencia. Le pregunté a Scholem por qué se admiraba a la señorita Arendt. Me dijo que ningún pensador serio la admiraba; que el carácter insólito de su obra atraía a los litérateurs, a los hombres de letras. Para los norteamericanos representaba el pensamiento continental. Pero, me dijo Scholem, ningún pensador verdaderamente cultivado y serio podía tolerarla. Eso pensaba Scholem, y la había conocido desde comienzos de la década de los veinte.

Y ahora, estas:

Con razón han hablado, quienes han analizado el terror de nuestro siglo, de la banalidad del mal. No es que el mal sea una banalidad. No, puede ser una monstruosidad. Lo que es banal, quienes son banales, son los sujetos que lo ejecutan. La educación es la réplica civilizada a la banalidad del mal y no puede perder de vista la sospecha de que el hombre convive, consciente o inconscientemente, con ese mal elemental que amenaza con salir a la superficie e invadir el mundo de la vida.

Las primeras líneas son parte de la entrevista que concedió I. Berlin a R. Jahanbegloo. ${ }^{1}$ Las segundas pertenecen al libro Por los campos de exterminio de Reyes Mate. ${ }^{2}$ Si algo se puede concluir de esto, es que estamos ante una pensadora muy polémica e idiosincrática que irritó a mucha gente con sus reflexiones, aunque a ella no le importó. Su insobornable independencia, no traicionarse, ese era su distintivo.
Si Eichmann en Jerusalén fue un escándalo en los círculos judíos, otra obra que generó una fuerte polémica fue Sobre la revolución, por las conclusiones tan particulares y "personales" que extrajo de las revoluciones Francesa y Americana. El politólogo C. B. Mcpherson, en una discusión en Toronto, le espetaba que sus inauditas afirmaciones en materia política eran producto de definiciones que eran válidas solo para ella. El ensayista Martin Jay le acusaba por haber criticado el pen- 
samiento de Marx después de leerlo desde una perspectiva desacreditada de su obra. Personalmente creo que la obra de H. Arendt debe ser tenida en cuenta pues da qué pensar, lo que ya es suficiente. Su visión del ser humano como perspectiva una y única del mundo, como comienzo siempre nuevo, como ser capaz de juicio, su defensa insobornable de la vida, son aspectos que no debiéramos olvidar. Pero estoy muy lejos de aceptar que el siglo XX sea el de Hannah Arendt, como afirman sus seguidores. $Y$ este es el motivo de estas líneas.

El presente artículo no pretende ser una introducción o presentación de su pensamiento. Se centra en algunos de sus puntos de vista más controvertidos, conflictivos, discutidos y polémicos.

En primer lugar, abordaré la distinción entre la radicalidad o la banalidad del mal. ¿Cambió de opinión acerca del mal $\mathrm{H}$. Arendt tras el juicio de Eichmann? Y, si lo hizo, ¿por qué? ¿Qué vio en aquel criminal nazi que tanto le impresionó?

En segundo lugar, ¿vivió Eichmann bajo el imperativo categórico de Kant, tal y como aseguraba el acusado? Que un criminal de guerra intentara justificar su abominable comportamiento apelando a un filósofo que tanto se preocupó por la facultad del juicio causó indignación entre los asistentes, especialmente en Arendt. Pero ¿hay algo en la ética kantiana que le permita a un delincuente ampararse en ella?

En tercer lugar, la muy "particular" lectura de las revoluciones Francesa y Americana. Y recalco lo de "particular", porque si bien un texto admite lecturas variadas, no todas son iluminadoras. ¿Es la de Arendt es una de ellas? Además, ¿es la separación entre lo político y lo social que defiende comprensible? ¿Es cierto que la compasión es antipolítica? Porque, según Arendt, todas las revoluciones posteriores que se inspiraron en la Revolución Francesa fracasaron al ubicarla en el centro de su ideario. Pero ¿qué entiende Arendt por "compasión"?

Con relación al primer punto, sostendré que sí cambió de opinión y que la polémica que generó dicho cambio fue creada y alimentada por gente que no entendió o no quiso entender los argumentos de nuestra autora. Como se verá, $\mathrm{H}$. Arendt nunca consideró que el horror y la barbarie de los campos de concentración fueran nimiedades. Quien haya leído con un mínimo de atención Los orígenes del totalitarismo, su primera gran obra, no puede equivocarse acerca de la pretensión de Arendt de denuncia de un sistema que vuelve prescindibles a los seres humanos. El cambio de opinión se debió a un descubrimiento de Arendt durante el juicio de Eichmann: simplemente el acusado era incapaz de pensar. Si Arendt dio tanta importancia en 
su obra posterior al pensamiento $y$ al juicio fue, entre otras cosas, porque Eichmann era el ejemplo de alguien que nunca ejerció estas facultades. Pero ¿qué entiende por "pensar" Arendt? La seguiremos en sus agudas reflexiones, porque es uno de los aspectos más valiosos de su obra. Recuérdese que Simone Weil, una ensayista diametralmente opuesta a Arendt, no solo nos advertía de que un hombre se vuelve esclavo cuando todos sus gestos proceden de otras fuentes que su pensamiento, sino de lo equivocados que estaríamos si creyéramos que los totalitarismos acabaron con el pensamiento libre, porque es justo lo contrario, la ausencia de este facilitó la emergencia de aquellos.

Como decía, ante el estupor general, Eichmann se declaró kantiano durante un interrogatorio, de ahí que en este segundo punto, aunque pueda parecer tangencial —-tiene más que ver con Kant y Eichmann que con $\mathrm{H}$. Arendt-, me detenga porque considero que vale la pena examinar algunas de las críticas que se han hecho a la ética kantiana, por las posibles contradicciones que encierra. Además, el libro de M. Onfray, El sueño de Eichmann, ${ }^{3}$ es muy sugerente, y si creemos en su tesis, Eichmann leyó y comprendió bien a Kant, lo que sería muy grave, porque de ser así el asesinato en masa encontraría justificación en el imperativo categórico. Intentaré mostrar que la tesis de Onfray no se sostiene si se lee la obra de Kant a la luz de la idea de "pro- greso" que empapa y atraviesa la obra del pensador de Könisberg. De ahí mi total acuerdo con la indignación de Arendt: Eichmann era incapaz de pensar, y menos kantianamente.

En el tercer punto, defenderé que la lectura arendtiana de las revoluciones Francesa y Americana es inconsistente, pues a la hora de detectar la ruina de la primera pone el acento, por un lado, en la absorción de lo político por lo social, mientras que, por otro, demuestra que ya desde el inicio la revolución estaba muerta al sustituir un principio absoluto por otro. Además, la tajante separación de lo político y lo social es, desde mi punto de vista, insostenible $y$, como advertía, cuestiona seriamente lo atractivo de su pensamiento, pues no solo convierte la política en un mero procedimiento, sino que además la deja en manos de elites. Asimismo, considero muy insuficiente el tratamiento que recibe la "compasión" —un simple sentimiento- en el pensamiento arendtiano, porque la autora carece de una teoría de la justicia -0 de la injusticia, según se vea-, como intentaré mostrar.

Puesto que vamos a internarnos en aquellas zonas del pensamiento arendtiano más resbaladizas o polémicas, he preferido presentar las citas textuales y después comentarlas para que el lector tenga una idea más precisa y pueda sacar sus propias conclusiones. En otras palabras, preservar el contexto para que prevalezca el texto. 


\section{I- ¿Mal radical o mal banal?}

Es bien sabido que Hannah Arendt era una asidua lectora de Kant, y es en la obra de este filósofo de la Ilustración donde encuentra una primera reflexión acerca del mal radical. Recordemos lo que este crítico de la razón escribía en 1793:

Pues bien, si en la naturaleza humana reside una propensión natural a esta inversión de los motivos, entonces hay en el hombre una propensión natural al mal; y esta propensión misma, puesto que ha de ser finalmente buscada en un libre albedrío y, por lo tanto, puede ser imputada, es moralmente mala. Este mal es radical, pues corrompe el fundamento de todas las máximas; a la vez, como propensión natural, no se lo puede exterminar mediante fuerzas humanas, pues esto solo podría ocurrir mediante máximas buenas, lo cual no puede tener lugar si el supremo fundamento subjetivo de todas las máximas se supone corrompido; sin embargo, ha de ser posible prevalecer sobre esta propensión, pues ella se encuentra en el hombre como ser que obra libremente. Por lo tanto, la malignidad de la naturaleza humana no ha de ser llamada maldad si esta palabra se toma en sentido estricto, a saber: como una intención (principio subjetivo de las máximas) de acoger lo malo como malo por motivo impulsor en la máxima propia (pues esta intención es diabólica), sino más bien perversidad del corazón, el cual por consecuencia se llama también mal corazón. ${ }^{4}$

Sabemos que en la ética kantiana, dado su carácter formal, lo que merece el calificativo de moral o inmoral no es el acto, sino la voluntad que se determina. Más aún, la moralidad está en la máxima de la acción y no en la acción misma, y por máxima de una acción debe entenderse el motivo o fundamento que mueve a una voluntad a querer y a realizar la acción. La inversión de los motivos no sería sino la elección de una máxima incorrecta, lo que derivaría en una acción inmoral. Esto es comprensible ya que no somos ángeles. Pero lo que Kant descarta por completo es la maldad en sentido estricto, o como dice, acoger lo malo como malo como motivo o fundamento, y así prefiere hablar de perversidad.

Arendt, en primera instancia, no comparte la opinión de Kant, y en Los orígenes del totalitarismo escribe: 
Y si es verdad que en las fases finales de totalitarismo aparece este como un mal absoluto (absoluto porque ya no puede ser deducido de motivos humanamente comprensibles), también es cierto que sin el totalitarismo podíamos no haber conocido nunca la naturaleza verdaderamente radical del mal. ${ }^{5}$

Y esta naturaleza radical del mal Arendt la encontraba en los sistemas totalitarios, sistemas que volvían superfluos a los seres humanos, pues solo así se consumaba el ideal de la dominación total; sistemas que perseguían la transformación misma de la naturaleza humana. Esta dominación se daba en tres pasos. El primero consistía en asesinar a la persona jurídica del ser humano. En el segundo, se aniquilaba a la persona moral. $Y$ en el tercero, se asesinaba al individuo. La originalidad del totalitarismo no se debía a la introducción de una nueva idea, sino al hecho de que su aparición había pulverizado la tradición, las categorías del pensamiento político y nuestros criterios de juicio moral, y lo que deseaba Arendt era comprender este fenómeno sin precedentes, este acontecimiento. ${ }^{6}$ Quede claro que comprender no es perdonar. Comprender es una actividad sin fin que nos permite reconciliarnos con la realidad, de sentirnos en armonía con nuestro mundo. Comprender es una actividad sin término que no produce resultados definitivos, es el modo de estar vivos; de ahí que de producir algún resultado, este sería el sentido que vamos generando a lo largo de nuestra vida. Y para Arendt, comprender el totalitarismo era acuciante porque era un fenómeno sin precedentes que había roto la tradición, que nos había alejado del mundo:

La política totalitaria afirma transformar a la especie humana en una portadora activa e infalible de una ley, a la que de otra manera los seres humanos solo estarían sometidos pasivamente y de mala gana. ${ }^{7}$

Esta ley para Arendt podía ser bien la de la Naturaleza, bien de la Historia. Goebbels, por ejemplo, apelaba al Destino. En cualquier caso, eran consideradas en los sistemas totalitarios como fuentes de cualquier legislación positiva.
Arendt siguió manteniendo su postura, la afirmación del mal radical en los sistemas totalitarios, hasta que asistió al juicio de Adolph Eichmann en Jerusalén, en el año 1961, como enviada especial del periódico New Yorker. Los artículos 
publicados vieron posteriormente la forma de libro, libro cuyo título desencadenó un escándalo, sobre todo en la comunidad judía: $E i$ chmann en Jerusalén. Un estudio sobre la banalidad del mal. ${ }^{8} \mathrm{~A}$ partir de entonces, cambió de parecer y comenzó a reflexionar acerca de la banalidad del mal. Eichmann era un teniente coronel de las SS, responsable de la solución final, ${ }^{9}$ encargado de la deportación de centenares de miles de judíos a los campos de concentración. ¿Por qué ese giro? ¿Eligió mal el calificativo? $\mathrm{Si}$ consultamos en el diccionario el término banal, encontramos tres calificativos: trivial, común, insustancial. Y esto es lo que vio Arendt en el criminal Eichmann, un hombre trivial, común e insustancial. Si Eichmann representaba el mal, este no podía ser sino banal:

Seis psiquiatras habian certificado que Eichmann era un hombre normal. "Más normal que yo, tras pasar por el trance de examinarle", se dijo que había exclamado uno de ellos. Y otro consideró que los rasgos psicológicos de Eichmann, su actitud hacia su esposa, hijos, padre y madre, hermanos, hermanas y amigos era no solo normal, sino ejemplar. $Y$, por último, un religioso que le visitó regularmente en la prisión, después de que el Tribunal hubiera denegado su último recurso, declaró que Eichmann era un hombre con ideas muy positivas. Tras las palabras de los expertos en mente y alma, estaba el hecho indiscutible de que Eichmann no constituía un caso de enajenación en el sentido jurídico, ni tampoco de insania moral. (...) Eichmann tampoco constituía un caso de anormal odio hacia los judíos, ni un fanático antisemita, ni tampoco un fanático de cualquier otra doctrina. ${ }^{10}$

Lo que quedaba claro es que no era el monstruo que todos esperaban ver y oír. Era simplemente un hombre peligrosamente normal. El fragmento siguiente es de especial relevancia ya que, como veremos, Eichmann se considerará seguidor de Kant, algo que dejaría perplejo a los asistentes del juicio y que daría mucho que pensar a Arendt. El 8 de mayo de 1945, fecha oficial de la derrota de Alemania, el acusado reflexionó de esta manera:

Comprendí que tendría que vivir una difícil vida individualista, sin un jefe que me guiara, sin recibir instrucciones, órdenes ni representaciones, sin reglamentos sin consultar, 
en pocas palabras, ante mí se abría una vida desconocida que yo nunca había llevado. ${ }^{11}$

¿Cómo puede un admirador palabras de ese tratadito titulado de Kant llegar a esta conclusión? ¿Qué es la llustración?:

Quizá Eichmann olvidó las primeras

Ilustración significa el abandono por parte del hombre de una minoría de edad cuyo responsable es él mismo. Esta minoría de edad significa la incapacidad para servirse de su entendimiento sin verse guiado por algún otro. ${ }^{12}$

Eichmann no tuvo tiempo ni deseos de informarse sobre el partido cuyo programa ni siquiera conocía. Tampoco había leído Mein Kampf. Cuando le preguntaron por qué no ingresaba en las SS, contestó lacónicamente: "¿Por qué no?" Se consideraba un idealista - el hombre que vive para su idea-, y para demostrarlo juró que hubiese envia- do a la muerte a su propio padre si se lo hubieran ordenado. No solo cumplía las órdenes que recibía, sino que además recalcó el gusto que sentía al cumplirlas. Por eso era un idealista. Se jactaba también de saber hacer dos cosas mejor que los demás: organizar y negociar. En los últimos días de la guerra dijo a sus hombres:

Saltaré dentro de mi tumba alegremente, porque el hecho de que tenga sobre mi conciencia la muerte de cinco millones de judíos - o enemigos del Reich, como siempre aseguró haber dicho- me produce una extraordinaria satisfacción. ${ }^{13}$

Arendt recalca que si algo quedó de manifiesto a lo largo del juicio era la incapacidad de Eichmann para considerar cualquier asunto desde el punto de vista de su interlocutor. Su lenguaje era estric- tamente burocrático — los campos de concentración eran asunto de administración y los de exterminio, de economía-, de manera que ante cualquier pregunta, siempre respondía con clisés:

Cuanto más se le escuchaba, más evidente era que su incapacidad para hablar iba estrechamente ligada a su incapacidad para pensar, particularmente para pensar desde el punto de vista de otra persona. No era posible establecer comunicación con él, no porque mintiera, sino porque estaba rodeado por la más segura de las protecciones contra 
las palabras y la presencia de otros, y por ende contra la realidad como tal. ${ }^{14}$

Norbert Bilbeny, en la misma línea, apunta que si Eichmann no pensaba, esto no se debía a una decisión suya ni a su falta de entendimiento, sino porque era un rasgo de su personalidad. ${ }^{15}$ Eichmann no mentía, y ipor qué habría de hacerlo? El pasado no le preocupaba, él y el mundo en el que vivió estaban en perfecta armonía. Su conciencia estaba tranquila porque no halló a nadie en su entorno que se mostrara contrario a la Solución Final. Para Arendt, la experiencia totalitaria eliminaba cualquier posibilidad de solitud —ella distinguía entre "solitud" y "soledad" - y por lo tanto de pensar; así, no es extraño que la conciencia dejara de funcionar. Por ello, a pesar de los esfuerzos que hizo el fiscal por presentarlo como un monstruo, estaban ante un payaso. Afirmó enfáticamente que jamás se debía prestar juramento, pero cuando tuvo que declarar en su propia defensa, lo hizo. Era un idiota moral, y como tal, no sentía las contradicciones. B. Bettelheim afirmaba en esta misma línea que, si los comandantes de los campos de concentración hubiesen tenido la capacidad para verse realmente cómo eran, no lo habrían resistido un momento más:

No tuvo Eichmann ninguna necesidad de cerrar sus oídos a la voz de la conciencia, tal como se dijo en el juicio, no, no tuvo tal necesidad debido, no a que no tuviera conciencia, sino a que la conciencia hablaba con voz respetable, con la voz de la respetable sociedad que le rodeaba. ${ }^{16}$

Arendt, que había reconocido no haber podido contener la risa por algunas de las respuestas del acusado, tampoco pudo contener su indignación por estas otras:

Durante el interrogatorio policial, cuando Eichmann declaró repentinamente y con gran énfasis, que siempre había vivido en consonancia con los preceptos morales de Kant, en especial con la definición kantiana de deber, dio un primer indicio de que tenía la vaga noción de que en aquel asunto había algo más que la simple cuestión del soldado que cumple órdenes claramente criminales, tanto en su naturaleza como por la intención con que son dadas. Esta afirmación resultaba especialmente indignante, y también incomprensible, ya que la filosofía moral de Kant está tan 
estrechamente vinculada a la facultad humana de juzgar que elimina en absoluto la obediencia ciega. ${ }^{17}$

¿Es esto completamente cierto? ¿No es Kant el acérrimo defensor de la obediencia ciega? Lo dejaré por ahora. Después de oír a Eichmann decir "que él fue una víctima y no un verdugo", "que jamás mató a nadie", "que lo que le preocupaba era no hacer daño innecesariamente", "que trabajó eficientemente", Arendt concluye con esta reflexión que resultaría irritante para muchos colectivos, especialmente el judío:

Fue como si en aquellos últimos minutos resumiera la lección que su larga carrera de maldad nos ha enseñado, la lección de la terrible banalidad del mal, ante la que las palabras y el pensamiento se sienten impotentes. ${ }^{18}$

Pero ¿qué significa banal para nuestra autora? G. Scholem le envió una carta pidiéndole una serie de explicaciones por algunas afirmaciones en asuntos un tanto resbaladizos. Arendt le contestó con otra fechada el 20 de julio de 1963 en la que, después de dejar muy clara su independencia intelectual, se refiere al problema del mal en estos términos:

Tiene usted toda la razón: I changed my mind y he dejado de hablar del mal radical. Hace mucho que no nos hemos visto. En caso de hacerlo, quizá hubiésemos terminado hablando del tema. No veo por qué se refiere usted a la expresión "banalidad del mal" como una "consigna". Por lo que yo sé, nadie ha utilizado todavía dicha expresión. Pero qué más da. Hoy en día pienso, efectivamente, que el mal es siempre solo extremo, pero nunca radical; que no tiene profundidad, ni nada de demoníaco. Puede devastar el mundo, justamente, porque es como un hongo que prolifera en la superficie. Profundo y radical es siempre solo el bien. ${ }^{19}$

El mal no es pensable porque carece justamente de raíces, de ahí que tampoco pueda ser radical. Arendt ya no cambiaría su opinión acerca del mal, el mal es banal. $Y$ no puedo estar de acuerdo con Richard J. Bernstein ${ }^{20}$ cuando afir- ma que Arendt nunca cambió de opinión, porque sí lo hizo y además reconocido precisamente por la propia autora. Lo que nunca cambió, en lo que se mantuvo siempre firme Arendt fue en su denuncia sin paliativos de los brutales aconte- 
cimientos vividos. Solo podemos pensar lo que tiene raíces, y el mal no las tiene. En una entrevista concedida años después aseguraba que no era ella la que había despojado a Eichmann de su componente demoníaco, que fue él quien lo hizo cayendo incluso en lo grotesco. Lo único que ella había pretendido era mostrar cómo se presenta lo demoníaco cuando uno lo contempla de cerca. $Y$ añadía que lo que nos cuesta asumir del pasado no es el número de víctimas, sino la vulgaridad de unos asesinos sin conciencia de culpa. Arendt reconoció que el subtítulo de su obra pudo molestar y ser controvertido, pero ella hablaba de la banalidad del mal de forma objetiva y que solo se limitaba a constatar un fenómeno que a lo largo del juicio fue evidente. El juicio de Eichmann fue para Arendt toda una revelación que no solo cambió su forma de pensar, sino que le abrió caminos por los que transitaría hasta el final. No es una casualidad que dedicara tantas páginas al pensamiento, al juicio o a la voluntad. Para ella, el totalitarismo no era un sistema político más, era justamente lo contrario de la política, porque en esta se dan relaciones entre los hombres, y Eichmann era - si puede decirse así- una mónada impenetrable, un sujeto atomizado.

Estas reflexiones de Arendt durante el juicio de Eichmann demuestran que la polémica por la banalidad del mal la alimentaron quienes no entendieron o no quisieron entender la obra de Arendt. Pensar era pensar después de Auschwitz, y por eso ella nunca minimizó ni minusvaloró este sobrecogedor acontecimiento. Lo único que pretendía era comprender. $\mathrm{Y}$, por si cupiese alguna duda,

Hasta entonces, uno se decía: bueno, tenemos enemigos. Es algo completamente natural. ¿Por qué no habría de tener enemigos un pueblo? Pero lo otro fue completamente distinto. Era como si se hubiera abierto un abismo. Porque uno pensaba que todo lo demás hubiera podido recomponerse de alguna manera, ya que en política todo se deja recomponer de alguna manera. Pero esto no. Esto no debería haber sucedido nunca. Y no me refiero al número de víctimas. Me refiero al empleo de cadáveres en un proceso de producción industrial y a todas esas cosas en las que no necesito entrar. Esto no debería haber sucedido. Porque lo sucedido es algo que ninguno de nosotros logrará quitarse de encima. ${ }^{21}$

Arendt creía que en política todo se deja recomponer de alguna manera. ¿Cómo? Por el perdón. El perdón no es amnesia que borra lo 
ocurrido. El perdón hace posible el comienzo de una nueva acción, que la vida continúe, que lo que se rompió se recomponga. Aparece de forma inesperada, no como la venganza, que es premeditada. Pues bien, $\mathrm{H}$. Arendt era de la opinión de que lo ocurrido ni se podía castigar ni perdonar por la enormidad del acontecimiento.

El gran descubrimiento clave del juicio fue, para Arendt, la incapacidad para pensar del acusado. Veamos entonces qué significa pensar para ella.

\section{II- ¿Qué significa pensar?}

Arendt abordó este asunto en La vida del espíritu, obra que se dividía en las tres actividades básicas del espíritu: pensamiento, voluntad y juicio. El 4 de diciembre de 1975, la autora murió repentinamente y el texto quedó inacabado. En este artículo seguiremos un trabajo suyo que apareció en 1971 y muestra el impacto que tuvo para ella oír a Eichmann durante el juicio en Jerusalén. El título es El pensar y las reflexiones morales ${ }^{22}$ y se lo dedicó al poeta y ensayista $W$. H. Auden.

Comienza reconociendo su estupor al encontrarse con un ser que no era un estúpido, sino alguien sin capacidad para pensar, que se refugiaba en clichés:

Clichés, frases hechas, adhesiones a lo convencional, códigos estandarizados de conducta y de expresión cumplen la función socialmente reconocida de protegernos frente a la realidad, es decir, frente a los requerimientos que sobre nuestra atención pensante ejercen todos los acontecimientos y hechos en virtud de su misma existencia. ${ }^{23}$

Arendt nos recuerda que debemos a Kant la distinción entre conocer y pensar, pero como estaba inmerso en la tradición metafísica no supo sacar gran partido de ello. Y es que hay que aclarar desde ya lo que no es el pensamiento. El pen- samiento no lleva al saber como lo hacen las ciencias. El pensamiento no implica una sabiduría útil para la vida. El pensamiento no resuelve los enigmas del mundo. El pensamiento no da inmediatamente fuerzas para la acción:

En nuestro contexto y para nuestros propósitos, esta distinción entre conocer y pensar es crucial. Si la capacidad de distinguir lo bueno de lo malo debe tener algo que ver con la capacidad de pensar, entonces debemos poder "exigir" su ejercicio a cualquier persona que esté en su sano juicio, 
con independencia del grado de erudición o de ignorancia, inteligencia o estupidez que pueda tener. ${ }^{24}$

Al realizar esta distinción, Arendt nos está advirtiendo de que podemos encontrarnos con gente muy inteligente incapaz de pensar. $Y$ es que — si puede decirse asípara esta actividad inactiva, que es el pensar, no hay expertos, es una capacidad que posee cualquier ser humano. La característica principal del pensar es que interrumpe toda acción, toda actividad ordinaria. Otra característica del pensar es que se ocupa de objetos que están ausentes, alejados de la directa percepción de los sentidos. Esto no significa que nos retiramos del mundo, simplemente nos alejamos, experimentamos un presente que es actualidad. El pensamiento es una actividad discontinua e intermitente cuyas modalidades principales son el experimento y la crítica. Activamos el pensamiento desde nuestras propias experiencias, pues los actos mentales tienen como referencia intencional la realidad. Llegados aquí podríamos preguntarnos por los resultados que ofrece:

Si puede haber una respuesta, ésta solo puede proceder de la actividad de pensar por sí misma, lo cual significa que podemos rastrear experiencias y no doctrinas. ${ }^{25}$

Arendt propone como modelo a Sócrates:

Brevemente propongo tomar como modelo a un hombre que pensó sin convertirse en filósofo, un ciudadano entre ciudadanos, que no hizo nada ni pretendió nada, salvo lo que en su opinión, cualquier ciudadano tiene derecho a ser y a hacer. Habrán adivinado que me refiero a Sócrates y espero que nadie discutirá seriamente que mi elección esté históricamente justificada. ${ }^{26}$

Sócrates, un hombre que pensó sin convertirse en filósofo. Este matiz es de una importancia crucial para comprender el pensamiento de Arendt y para el presente artículo. $Y$ es que para Arendt las relaciones entre la política y la filosofía siempre fueron conflictivas, porque en su opinión, aparte de que la filosofía nunca tuvo un concepto claro de la política, los filósofos siempre trataron de hallar bases teóricas y formas prácticas para alejarse de ella. Arendt no concede a la vida contemplativa el grado de superioridad que otros le otorgaron, porque esa retirada del mundo en busca de las verdades eternas nos aleja del mundo de los mortales, de las apariencias. La libertad política necesita 
la presencia de los otros, por tanto, pluralidad, un espacio entre los hombres. El filósofo $-y$ está pensando en Platón - en busca de las ideas, marcha en la más completa soledad. Otro motivo para separarse de los filósofos es que mientras estos hablan de episteme, ella habla de doxa, no entendida como mera opinión sin fundamento, sino como aquello que se le aparecía a uno, y desde ella se asumía un mundo común para todos. Tras lo dicho, se entiende que tiene que ser Sócrates el elegido:

Lo primero que nos sorprende de los diálogos socráticos de Platón es que son aporéticos. La argumentación no conduce a ninguna parte o discurre en círculos. ${ }^{27}$

Ya sabíamos que el pensar no produce resultados, ni teóricos ni prácticos; entonces, ¿cuál es el resultado, a dónde nos lleva esto?

La palabra casa es algo semejante a un pensamiento congelado que el pensar debe descongelar, deshelar, por así decirlo, siempre que quiera adivinar su sentido original.

Eichmann no podía pensar porque quienquiera que se mueva en un mundo de frases hechas, de clichés, está totalmente blindado frente al pensamiento. Era un buen representante de lo que podríamos llamar conductismo lingüístico.

Pero hay más en la figura de Sócrates, porque además es un tábano que sabe cómo aguijonear a los atenienses para que despierten de su sopor y se pongan a pensar, a exa- minar sus vidas. Sócrates es también una comadrona, pues quiere purgar a la gente de sus opiniones y al proporcionarles su verdad, los ayuda a librase de lo malo, sin hacerlos buenos. Y por último, Sócrates es un torpedo que paraliza a cuantos toca manteniéndoles firmes en sus perplejidades. Recuérdese que Sócrates fue condenado a muerte por corromper a la juventud, entre otros cargos, porque el pensamiento tiene efectos destructivos:

El pensamiento tiene un efecto inevitablemente destructivo; socava todos los criterios establecidos, todos los valores y pautas del bien y del mal, en suma, todos los hábitos y reglas de conducta que son objeto de la moral y de la ética. ${ }^{28}$

Si pensar es peligroso — puede incluso conducirnos al nihilismo-, no pensar también tiene sus peligros. Eichmann es un claro ejemplo: 
Al sustraer a la gente de los peligros del examen crítico, se les enseña a adherirse inmediatamente a cualquiera de las reglas de conducta vigentes en una sociedad dada y en un momento dado. Se habitúan entonces menos al contenido de las reglas - un examen detenido de ellas los llevaría siempre a la perplejidad-que a la posesión de reglas bajo las cuales subsumir particulares. En otras palabras se acostumbran a no tomar nunca decisiones. ${ }^{29}$

Esta era la causa de desasosiego en Eichmann al concluir la guerra, ya no tenía reglas que seguir; y para un hombre sin capacidad para pensar, la situación era crítica. Dice Arendt que mientras pensamos nos retiramos del mundo, pero no nos quedamos solos, porque nos quedamos con nosotros mismos. Este es otro punto que destaca de Sócrates, del que extrae dos conclusiones: la primera es que cometer una injusticia es peor que padecerla. La segunda:

Es mejor que mi lira esté desafinada y que desentone de mí, e igualmente el coro que yo dirija, y que muchos hombres no estén de acuerdo conmigo y me contradigan, antes de que yo, que no soy más que uno, esté en desacuerdo conmigo mismo y me contradiga. ${ }^{30}$

Mientras uno es consciente, consciente de sí, es idéntico consigo mismo solo para los otros ante

los que aparece. Para uno mismo, cuando articulo este ser consciente, son dos en uno:

Pues este ego, el yo soy yo, experimenta la diferencia en la identidad precisamente cuando no está relacionado con las cosas que aparecen sino solo consigo mismo. ${ }^{31}$

El pensamiento en su proceso actualiza esta diferencia que se da en la conciencia, pues es diálogo del alma consigo misma, y este diálogo interior solo puede ser fértil si las dos partes son amigas. Volviendo a las dos frases socráticas, se entiende perfectamente su sentido: es mejor sufrir una injusticia que cometerla, porque podemos ser amigos de una víc- tima, pero nunca del victimario, del verdugo. Sócrates, cuando abandone el ágora, volverá a su casa, donde estará en solitud, que no en soledad, para encontrar a su otro compañero para seguir dialogando.

Arendt reconoce que el pensar beneficia poco a la sociedad, mucho menos que el conocimiento 
o el saber, y solo en momentos

ficado político y moral. Así, Julio críticos es cuando aflora su signi-

Quesada Martín afirma:

El mal banal no es ausencia de racionalidad moderna, sino la puesta en práctica del dominio del saber sobre el pensar, dicho de otro modo, la solución a la que llegaron los nazis después de "planteado" el problema por Hitler en 1941 - carta que recibe Heydrich el 31 de julio de Hermann Göring para que preparase la solución general del problema judío en la zona de influencia alemana en Europa", y que presentara una propuesta general... para la ejecución de la tan deseada solución final- no hubiera sido posible sin la profunda alianza moderna que se da entre burocracia y técnica. ${ }^{32}$

Cuando la mayoría se deja llevar por una auténtica hybris, el pensamiento puede convertirse en acción y su destructividad tiene un efecto liberador para otra facultad humana, el juicio, la más política de las capacidades mentales del ser humano. Y este es un punto crucial en el pensamiento arendtiano:

Es la facultad de juzgar particulares, sin subsumirlos bajo reglas generales que se enseñan y se aprenden hasta que se convierten en hábitos que pueden ser sustituidos por otros hábitos y reglas. ${ }^{33}$

Arendt, lectora de Kant, siempre declaró que había más pensamiento político en la Critica del juicio que en la Critica de la razón práctica, y esta es la muestra. Los juicios reflexionantes, en principio propios de la estética, son considerados como los juicios políticos por excelencia. Si la política no es el ámbito de los expertos sino de todos; si no hay conocimientos sino opiniones, el juicio reflexionante cumple estos requisitos, pues al emitirse sobre un particular sin regla general que lo acoja, aunque quien lo emite lo haga con pretensión, pero solo con pretensión, de universali- dad, abre un debate entre los interlocutores que ya nunca se cerrará. J. Habermas, en su Teoría de la acción comunicativa, tomará buena nota de esto. Lo contrario sería el juicio determinante, propio de las ciencias, que por encontrar reglas universales puede producir conocimiento, pero el pensamiento, ya lo sabemos, no produce ningún resultado. Pero la facultad de juzgar, "esto es malo", no coincide con la facultad de pensar. $\mathrm{Si}$ el pensar opera con invisibles, el juicio se ocupa de particulares y cosas que están a la mano. Son distintas capacidades pero interconectadas: 
Si el pensar, el dos en uno del diálogo silencioso, actualiza la diferencia dentro de nuestra identidad, dada en la conciencia, y por ello produce la conciencia como subproducto, entonces el juzgar, el subproducto del efecto liberador del pensar, realiza el pensamiento, lo hace manifiesto en el mundo de las apariencias, donde nunca estoy solo y siempre demasiado ocupado para pensar. La manifestación del viento del pensar no es el conocimiento; es la capacidad de distinguir lo bueno de lo malo, lo bello de lo feo. Y esto, en los raros momentos en que se ha llegado a un punto crítico, puede prevenir catástrofes, al menos para mí. ${ }^{34}$

Si para Arendt la política es la actividad por excelencia del ser humano, y dicha actividad se asienta en la capacidad de pensar y de juzgar, Eichmann que, como ya se ha repetido, carecía de la facultad de pensar, estaría fuera de la política, así como el sistema que representaba. Más aún, si Eichmann era incapaz asimismo de desdoblarse, de encontrar esa diferencia en la identidad, de ver ese dos en uno que constituye al ser humano, jamás supo que vivió toda su vida con un criminal como compañero.

Hasta aquí, el comportamiento de Eichmann. Pero resta por saber si, como dijo en los interrogatorios, dicho comportamiento se ajustaba a la ética kantiana, lo que tanto indignó a Arendt.

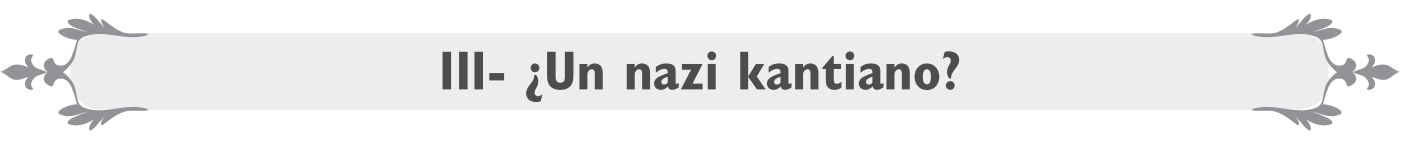

No llegaré tan lejos como $\mathrm{M}$. Onfray, El sueño de Eichmann ${ }^{35}$, al asegurar que el sistema kantiano es compatible con el nazismo porque de las lecturas que pueden hacerse de un texto no es responsable el autor. Alasdair Maclntyre ${ }^{36}$ cree en principio que quien haya sido educado en la noción kantiana de deber, "habrá sido educado en un fácil conformismo con la autoridad"; pero añade inmediatamente que esto está muy lejos de las intenciones y del espíritu de Kant. En cualquier caso, concluye que una ética como la kantiana, independiente del orden social, de los deseos y de las necesidades de los seres humanos concretos, puede dar lugar a consecuencias perversas. Pero volviendo al libro de M. Onfray, hay que reconocer que da qué pensar; $y$ es que son tan contundentes en algunos casos los textos kantianos, que vale la pena detenerse en ellos.

Recordemos el imperativo categórico de Kant: "Obra solo de forma que puedas desear que la máxima de tu acción se convierta en una ley universal". Este es el de Hans Frank, alto funcionario nazi condenado $y$ 
ejecutado en 1946: "Compórtate de tal manera que si el Führer te viera, aprobaría tus actos". La Ley del Funcionariado, para Arendt una parodia también del imperativo kantiano, ordenaba: "Actúa como si el fundamento de tu actuación fuera el mismo que el del legislador o el de las leyes de la tierra". El deontologismo se impone en estas máximas, es decir, el cumplimiento del deber porque es el deber, ese es el valor. Eichmann obedeció la ley porque era la ley. Leamos ahora algunos fragmentos kantianos en los que el acusado se "inspiró":

De aquí se sigue, pues, el principio: el soberano en el Estado tiene ante el súbdito solo derechos y ningún deber (constrictivo). Además, si el órgano del soberano, el gobernante, infringiera también las leyes, por ejemplo, procediera contra la ley de la igualdad en la distribución de las cargas públicas, en lo que afecta a los impuestos, reclutamientos, etc., es lícito al súbdito quejarse de esta injusticia, pero no oponer resistencia. ${ }^{37}$

El súbdito solo tiene deberes, y Eichmann los cumplió con eficacia, diligencia y eficiencia, porque ese era su deber:

Contra la suprema autoridad legisladora del Estado no hay, por tanto, resistencia legítima del pueblo; porque solo la sumisión a su voluntad universalmente legisladora posibilita un estado jurídico; por tanto, no hay ningún derecho de sedición, aún menos de rebelión, ni mucho menos existe el derecho de atentar contra su persona, incluso contra su vida como persona individual, so pretexto de abuso de poder. El menor intento en este sentido es un crimen de alta traición y el traidor de esta clase ha de ser castigado, al menos, con la muerte como alguien que intenta dar muerte a su patria. La razón por la que el pueblo debe soportar, a pesar de todo, un abuso del poder supremo, incluso un abuso considerado como intolerable, es que su resistencia a la legislación suprema misma ha de concebirse como contraria a la ley, incluso como destructora de la constitución legal en su totalidad. ${ }^{38}$ 
El súbdito no puede oponer resistencia, y Eichmann lo acató porque ese era su deber:

Este problema es también el más difícil y el que más tardíamente resolverá la especie humana. La dificultad que ya la mera idea de la tarea nos patentiza es la siguiente: el hombre es un animal que, cuando vive entre sus congéneres, necesita un señor. (...) Necesita un señor que le quebrante su propia voluntad y le obligue a obedecer a una voluntad verdadera para todos, para que cada cual pueda ser libre. Pero ¿de dónde escoge este señor? De la especie humana, claro está. (...) El jefe supremo tiene que ser justo por sí mismo y, no obstante, un hombre. ${ }^{39}$

Este jefe supremo justo por sí debía lealtad porque ese era su mismo era Hitler, a quien Eichmann deber:

Se puede considerar la historia de la especie humana en su conjunto como la ejecución de un secreto plan de la Naturaleza, para la realización de una constitución estatal interiormente perfecta, y, CON ESTE FIN, también exteriormente, como el único estado en que aquélla puede desenvolver plenamente todas las disposiciones de la humanidad. ${ }^{40}$

Esto es justamente lo que denunciaba Arendt en los totalitarismos. Afirmaba que estos sistemas querían cambiar la naturaleza

humana siguiendo una "ley" de la Naturaleza o de la Historia. Los nazis conocían este plan secreto y lo ejecutaron porque era su deber:

Ciertamente, resultaría muy pernicioso que un oficial, a quien sus superiores le hayan ordenado algo, pretendiese sutilizar en vOz alta y durante el servicio sobre la conveniencia o utilidad de tal orden; tiene que obedecer. Pero en justicia no se le puede prohibir que, como experto, haga observaciones acerca de los defectos del servicio militar y los presente ante su público para ser enjuiciados. ${ }^{41}$

Quizá Eichmann hiciese alguna observación, pero lo seguro es que siempre obedeció porque era su deber: Razonad cuanto queráis y sobre todo cuanto gustéis, jcon tal de que obedezcáis! ${ }^{42}$ Es más importante obedecer que razonar; y más allá de lo que Eichmann "razonara", obedeció porque era su deber. 
Parece pues encajar la vida de Eichmann en el imperativo categórico, pero este supone algo más. Adela Cortina cierra un brillante artículo dedicado a la ética kantiana en el que defiende su "esplendor" ${ }^{\text {"43 }}$ remitiéndose a una cita del Principio esperanza de Bloch. En ella, Bloch nos recuerda la importancia de ese imperativo categórico kantiano que nos prohíbe tratar a los seres humanos como medios, pues son fines. Es decir, nos advierte simplemente del reconocimiento de la dignidad humana. Y es que este imperativo no es uno más, es la base, es el fundamento de los demás. Este imperativo es tan determinante que no se cumple en ninguna sociedad clasista. A. Cortina va más lejos y afirma:

El contenido ético de la forma de la voluntad pura no puede realizarse, según Horkheimer y Bloch, ni en una sociedad burguesa ni en una sociedad dividida en clases. Sin embargo, yo deseo ir más lejos: la afirmación kantiana del fin en sí mismo no puede realizarse en ninguna sociedad que instrumentalice todas las cosas, que establezca entre ellas equivalencias dirigidas a determinar su precio para el intercambio. Si todo es medio para otra cosa, es posible universalizar la ley del precio, comparando utilidades. ${ }^{44}$

El ser humano tiene dignidad, nunca precio. Eichmann no entendió nada de esto ni podía entenderlo, porque nunca pensó. Si alguien que se declaraba kantiano por haber vivido su vida según el imperativo categórico ignoraba el contenido de este - base y fundamento de los demás-, simplemente mentía o lo ignoraba, de ahí la indignación de Hannah Arendt. Pero, ¿qué es el ser humano para Kant? Olvidemos el racismo que se destiló en la obra de los filósofos ilustrados, verdaderos disparates, y centrémosnos en una crítica más analítica.

En la obra ya citada, Esplendor y miseria de la ética kantiana, podemos leer otro brillante artículo, esta vez de Esperanza Guisán, ${ }^{45}$ en el que se ponen de manifiesto algunas de las limitaciones. Veámoslas.

La primera limitación para Guisán, la "cruz de la ética kantiana", radica en ser una visión masculina del fenómeno moral que deja de lado los sentimientos y propósitos de los seres humanos:

En dos sentidos especialmente, que en el fondo son el anverso y el reverso de un mismo problema, se encuentra la ética kantiana particularmente deficitaria: 
1.- La concepción de la razón práctica como razón pura, a priori, no condicionada empíricamente y la autonomía del agente frente a las leyes de la sensibilidad.

2.- La escisión del hombre sensible y el hombre racional, la tajante ruptura entre lo deseado y lo deseable, y, por ende, la imposible conexión, aquí y ahora entre felicidad $y$ virtud. ${ }^{46}$

De estas escisiones, Guisán concluye que es falaz la presunta autonomía de la voluntad. ¿Quién es el sujeto legislador? No será el ser humano viviente de carne y hueso. Será algo así como una entelequia que, fuera del mundo, considera los deberes como mandatos de un ser supremo. Esta escisión kantiana entre lo racional y lo emocional es producto del una concepción del ser humano como egoísta e incapaz de albergar sentimientos de solidaridad, empatía y benevolencia, de ahí que estos nunca puedan ser base firme de la moralidad. ¿Cómo define Kant el sentimiento? Esto es importante aclarar pues, como veremos, el tratamiento que recibe la "compasión" en el pensamiento arendtiano no se separa de la ética kantiana:

Se llama sentimiento a la capacidad de experimentar placer o desagrado en virtud de una representación, porque ambos contienen lo meramente subjetivo en relación con nuestra representación y ninguna referencia a su posible conocimiento. ${ }^{47}$

$\mathrm{Si}$ —como bien apunta Manuel García Morente ${ }^{48}$ - la ética kantiana es una reflexión acerca de la moral, de las morales, para aislar y descubrir los caracteres universales y perennes de todo ideal moral, los sentimientos meramente subjetivos no tienen cabida. El formalismo y la universalidad operan a través de la abstracción, es decir, prescinden de los "accidentes" para quedarse con la "sustancia"; el problema es que son los "accidentes" y no la "sustancia" los que nos ubican en un mundo común, un mundo compar- tido, un mundo en el que no cabe separar virtud y felicidad.

Guisán da la razón a Kant cuando asegura que el ser humano busca la autodeterminación, la ilustración y el esclarecimiento, pero no para liberarse de las pasiones, como él supone, sino para expandirlas, remodelarlas y hacerlas más plenas y gratificantes. ${ }^{49}$ Especialmente relevante para la tercera parte de este artículo es el párrafo siguiente: 
El sentimiento de compasión y de simpatía tierna, cuando precede a la reflexión sobre qué sea el deber y se convierte en fundamento de determinación, es pesado incluso a las personas que piensan bien... y produce el deseo de liberarse de él y someterse solo a la razón legisladora. ${ }^{50}$

La crítica a la ética kantiana de do por Esperanza Guisán: M. Onfray va en el sentido apunta-

Kant es culpable - y con él también lo es el kantismo- de razonar alejado de la realidad del mundo, de la gente, de los hombres, como el habitante cándido del cielo de las ideas que tanto hacía reír a Aristófanes con la camarilla platónica. ${ }^{51}$

En resumen, concluye Onfray, lo nocivo en la ética kantiana es esa falta del derecho a desobedecer, y Eichmann nunca desobedeció una orden, era su deber y lo cumplía a la perfección. ¿Por eso era kantiano? A mi juicio, no. Kant es un hombre del siglo XVIII y Eichmann, del $X X$, lo que no debe olvidarse porque el filósofo de Könisberg es hijo del despotismo ilustrado y arrastraba las contradicciones de ese espíritu, contradicciones que se resumen en el famoso lema: "Todo para el pueblo, pero sin el pueblo". Si Kant hace tanto hincapié en la obediencia, no es pensando en el mundo militar, sino en el mundo de la razón. Luis Sánchez Agesta lo deja muy claro en su análisis del despotismo ilustrado, cuando hace referencia a la minoría ilustrada y a la educación del pueblo:

El siglo XVIII ha descubierto el pueblo como público de la vida intelectual y política. Los libros políticos dejan de estar concebidos como instrucciones para el príncipe o sus ministros, y aunque en muchos casos mantengan la misma orientación pedagógica, ya no es al rey, sino al pueblo, a quien se pretende educar. Lo ha descubierto, todo hay que decirlo, con un extraño sentimiento mixto de atención afectuosa y desprecio, y en gran parte como elemento necesario de contraste, como el liso y macizo pedestal sobre el que la ilustración alza más airosas las gracias de su razón. No puede existir una aristocracia sin clases inferiores sobre las que destaque, y la minoría ilustrada no tendría conciencia de su aristocracia intelectual sin la multitud iletrada del vulgo, a la que se contrapone. ${ }^{52}$ 
Este fragmento resume perfectamente el espíritu de esa época, libros para el pueblo, el pueblo como motivo de atención y de desprecio, minoría ilustrada frente al vulgo ignorante. Atrévete a saber, por su- puesto, pero no olvides nunca que hay otros que saben mucho más que tú y, por tanto, a los que debes obedecer. $Y$ esto tiene que ver con algo que no debemos olvidar: al vulgo no se le enseña todo.

Lo que se hace público para la educación del pueblo no coincide siempre con las convicciones de esa minoría directiva. La relación pedagógica es patente hasta en el modo y medida de la enseñanza. Junto a lo que se publica, esto es lo que se da para el público ignorante, está lo que solo se confía a la correspondencia particular, al cambio de ideas entre iniciados, que saben lo que todos no pueden saber. ${ }^{53}$

Hay por tanto dos tipos de saber. Por un lado, encontramos un saber exotérico, común, accesible para el vulgo; y otro esotérico, oculto y reservado, que se transmite solo a los iniciados. ¿No distingue Kant entre un uso privado y público de la razón? En una sociedad en la que solo hay dos estratos - los ilustrados (entre los que se encuentra Kant) y el vulgo iletrado-, el inferior "por su bien" tiene siempre que seguir, digámoslo así, las órdenes del superior. Se le anima desde el superior a que razone, pero que sobre todo obedezca.

Pero hay algo más. Onfray habla de deber y de obediencia, pero olvida que Kant fue un ferviente defensor de la Revolución Francesa. ¿Cómo salir de esta presunta incoherencia? Podemos encontrar dos. Veamos la primera. Uno de los mayores expertos en Kant, Roberto Aramayo, escribe en el prólogo de ¿Qué es la llustración?:

La interpretación más plausible - a mi parecer - es la de F. González Vicén, para quien no se trata de una contradicción o una inconsecuencia, sino de una doble perspectiva de uno y el mismo problema, advirtiendo que no debe confundirse una valoración de un hecho histórico con el enjuiciamiento del mismo problema bajo la luz de una insobornable lógica jurídica. ${ }^{54}$

Interpretación que comparto, pues esa insobornable lógica jurídica se manifiesta en el siguiente fragmento en el que Kant plantea el caso de una constitución que contuviera una ley para quebrantarla. Es decir, Kant lo que está defendiendo es la regla de coherencia: "En un 
ordenamiento jurídico no deben existir antinomias". Un sistema jurídico que contuviera normas antinó- micas se desmoronaría al no poder ordenar nada, pues cabría cualquier norma y su contraria ${ }^{55}$ :

Que la constitución contuviera una ley para tal caso, una ley que autorizara a derrocar la constitución vigente - de la cual dimanan todas las leyes particulares - en el supuesto de que el contrato fuera quebrantado, sería una clara contradicción, porque entonces habría de contener un contrapoder públicamente constituido y, por ende, sería preciso todavía un segundo jefe de Estado que amparase los derechos del pueblo frente al primero, e incluso un tercero que decidiese entre ambos para dirimir de parte de cuál de ellos está el derecho. ${ }^{56}$

Pero la segunda es la mejor, porque nos la da el propio Kant. Onfray olvida un punto crucial en la filosofía kantiana de la historia: el progreso. En un opúsculo que no tiene desperdicio, "Si el género humano se halla en progreso constante hacia mejor", leemos:

Esta revolución de un pueblo lleno de espíritu, que estamos presenciando en nuestros días, puede triunfar o fracasar, puede acumular tal cantidad de miseria y de crueldad que un hombre honrado, si tuviera la posibilidad de llevarla a cabo una segunda vez con éxito, jamás se decidiría a repetir un experimento tan costoso, y, sin embargo, esta revolución, digo yo, encuentra en el ánimo de todos los espectadores (que no están complicados en el juego) una participación de su deseo, rayana en el entusiasmo, cuya manifestación, que lleva aparejada un riesgo, no puede reconocer otra causa que una disposición moral del género humano. ${ }^{57}$

Y prosigue diciendo que ningún pueblo debe ser impedido para que se dé a sí mismo la constitución que bien le parezca. $Y$ es que el progreso moral supone cambios; y si estos no se producen, entramos en el estancamiento, y a esta posibilidad la llama "abderitismo". Eichmann pudo haberse rebelado, según Kant, y no lo hizo. Si Eichmann seguía fielmente las órdenes fue por su manifiesta incapacidad para pensar, actividad tan "incómoda" como fundamental. Y como él mismo reconocía, al acabar la guerra se encontraba atribulado, porque el sistema que pensaba por él había concluido y se encontraba 
a la intemperie. De buena gana se hubiese refugiado en otro similar, porque lo más importante para él era no pensar y cumplir órdenes. Que se declarara kantiano en aquel interrogatorio era simplemente una impostura, y de ahí la indignación más que comprensible de $\mathrm{H}$. Arendt.

\section{IV- La lógica de la revolución}

Fue la necesidad, las necesidades perentorias del pueblo, la que desencadenó el terror y la que llevó a su tumba a la Revolución. ${ }^{58}$

Esta es de forma resumida la tesis que defiende Arendt: en el momento mismo en el que la Revolución Francesa se preocupó de la miseria del pueblo, murió. En otras palabras, si los problemas sociales invaden el espacio político, este desaparece. Esta tesis causó un gran escándalo, como era previsible; pero es que además, Arendt defendía la bondad de la Revolución Americana ya que, al no caer en ese error, apostó decididamente por la política. La pregunta inmediata era: ¿qué hay de la esclavitud? ¿Se puede hablar de revolución cuando esta se asienta en una institución tan vergonzante e inhumana?

Más allá del asentimiento o no a la tesis de Arendt, en mi caso es de disentimiento, lo que me propongo en este epígrafe es mostrar que Sobre la revolución es un libro contradictorio, hasta el punto de arruinar su pensamiento político, fértil en muchos aspectos.
Sobre la revolución es un texto que, aparte de la introducción, se divide en seis capítulos. Después de hablar del significado de la revolución, Arendt aborda en el segundo capítulo "La cuestión social", en el que defiende la controvertida tesis expuesta y en el que arremete contra la "compasión" como sentimiento "que anula el espacio mundano interhumano donde están localizados los asuntos políticos, la totalidad de la actividad humana". En el tercero abunda en lo dicho en el segundo, pero lo más Ilamativo está en los capítulos cuarto y quinto, en los que demuestra que no es la cuestión social, sino que la revolución nació muerta por su lógica interna. Cierra el libro un sexto capítulo en el que Arendt escribe sobre el tesoro perdido de la tradición revolucionaria. Me centraré a continuación en los capítulos segundo, cuarto y quinto, y para ello comencemos recordando la tesis de un agudo comentarista de la Revolución Francesa, Ferenc Feher:

Mi tesis es que fue la lógica política (la lógica de la democracia o el proceso que aspiraba a crear una sociedad libre 
o una "república") la que se convirtió, desde la convocatoria de los Estados Generales hasta el hundimiento de la república, en la lógica permanentemente dominante y en consecuencia en el vocabulario dominante y común. Esta afirmación es contraria a la tesis de Hannah Arendt, según la cual la Revolución francesa emprendió el camino del liberticidio precisamente cuando comenzó a dar prioridad a lo social sobre lo político, a la satisfacción de las necesidades más que al desarrollo de una constitutio libertatis. Estoy de acuerdo con la conclusión de Arendt de que la revolución emprendió el camino del liberticidio pero no con su argumento. La supremacía de la lógica política solo fue cuestionada seriamente en un interludio gracias a la intervención del igualitarismo enragé. Pero ello fue rechazado por todos los otros protagonistas. ${ }^{59}$

¿Cómo funcionaba esa lógica política? Antes de volver a Feher, demos la palabra a otro especialista, Albert Soboul. Este ve en Robespierre a un clarividente que rápidamente comprendió las necesidades de la práctica revolucionaria. En primer lugar, estaban las necesidades políticas. Había que destruir el antiguo orden por el éxito de la revolución incurriendo en la violencia o en la ilegalidad. "¿Acaso la fuerza está hecha solo para proteger el crimen?", se preguntaba Robespierre. En segundo lugar, las necesidades morales. Convencido Robespierre de que la violencia revolucionaria puede caer en el exceso, debe ser corregida por la virtud. No se equivoca, a mi juicio, Arendt cuando denuncia esa creación del "hombre nuevo" que proclaman todas las revoluciones, y la francesa no fue una excepción. El "hombre revolucionario" era para Saint Just "inflexible, pero sensato, frugal; es sencillo sin ostentar el lujo de la falsa modestia; es enemigo irreconciliable de toda mentira, de toda indulgencia, de toda afectación... un hombre revolucionario es un héroe del sentido común y de la probidad". Y, por último, las sociales, la fuerza de las cosas, la lógica de la revolución: no es suficiente apoderarse del poder, es necesario además revolucionar las estructuras y las relaciones sociales. ${ }^{60}$ Retengamos términos como "violencia", "moralidad" y "hombre nuevo", porque están todos ellos en el punto de mira de Arendt. Y ahora volvamos con Feher.

¿Cuál fue la lógica política jacobina? Se descartaba de entrada una revolución desde arriba aplicada por el monarca y supervisada por el filósofo; el despotismo ilustrado no era solución. Además, si la marcha triunfal de la Razón no aparecía por ningún lado, quedaba en entredicho 
el pensamiento ilustrado. La crisis de la Ilustración desató la crisis en el jacobinismo, y en el centro de esta crisis estaba la doctrina de Rousseau. Por un lado, Rousseau rechazaba una naturaleza humana pecaminosa y, por otro, este carácter bondadoso chocaba con una sociedad artificial. A esto se añadía la dialéctica de la voluntad general, que no es la suma de las voluntades individuales, sino la de la "repúbli-

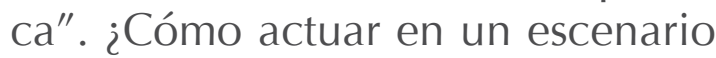
que no garantiza ninguna armonía? Según Feher, el revolucionario tenía dos remedios:

El primero es la división de su credo en una doctrina pública y otra "secreta", con la dificultad adicional de que, para evitar un maquiavelismo hipócrita, tiene que defender ambas posiciones con convicción. La doctrina pública es la de la perfectibilidad del ser humano. ${ }^{61}$

Con la perfectibilidad del ser humano se pone en marcha el proceso de creación del "hombre nuevo", tal y como lo define Saint Just. Esto se lograría a través del proceso revolucionario con instituciones republicanas. Se trataba de que al elevarse el pueblo a la virtud, la dialéctica de la voluntad general desaparecía. ${ }^{62}$

Para Rousseau, la sociedad civil no podía fundarse en el derecho natural, la sociedad civil exigía una moral que le permitiera vivir en sociedad, y como la moral no es natural, debería crearla. Esta es la base del "Contrato social", resolver el conflicto entre el individuo y el Estado de forma que la ley es la voluntad de cada quien pensando en términos de todos, y así es producto de la voluntad general. Dada la perfectibilidad del ser humano, podría lograrse resolver la dialéctica antes apuntada. Pero hay algo más, según Feher:

Por definición, puede decirse menos sobre la "doctrina secreta". (...) Sin embargo contamos con un apoyo sólido: el mismo Robespierre, cuyo pesimismo antropológico roussoniano, cuya creencia en que la virtud está siempre en minoría, se abren paso en sus ferrosas afirmaciones sobre "la bondad y la rectitud" del pueblo. Pero si la brecha entre la doctrina pública y la secreta no se salva con pura hipocresía, se convierte entonces en la tarea de un educador tiránico, un Sarastro que adopta la postura de la volonté général en su condición de minoría virtuosa, pero "naturalmente" isolo mientras dure el proceso revolucionario! ${ }^{63}$ 
¿Y cuánto dura el proceso revolucionario? Soubul nos recuerda que la diferencia entre reforma y revolución no se distinguen por su duración, sino por su contenido. No se trata de escoger una vía más rápida o más lenta que conduzca al mismo resultado, sino precisar un objetivo: o la instauración de una sociedad nueva o unas modificaciones superficiales en la antigua sociedad; además Soubul también nos recuerda que la transición no puede ser prolongada ${ }^{64}$. $Y$ aquí en- tra en acción el segundo remedio: la moralización de la política o, en su reverso, la politización de la moral. Una política "correcta" debía realizar la voluntad general, lo que suponía la bondad de los actores. ${ }^{65}$ ¿Quién o quiénes decidían el contenido de los valores morales que se tenían que reflejar en la política?: los jacobinos. Los jacobinos no eran la revolución, eran el ojo de la revolución, el ojo para vigilar, la voz para acusar, el brazo para golpear ${ }^{66}$. Volvamos a Feher.

La voluntad general era la voluntad de la república. Primero se hablaba de "nación" y después de "república", ¿por qué esta modificación? Los jacobinos vieron la categoría "nación" como excesivamente formal y la sustituyeron por la de "república", más esencial y que además comprendía dos elementos. En primer lugar era vista como la "sociedad", como la voluntad colectiva que contrastaba con la codicia, con la ambición, con el egoísmo individual. En segundo lugar era fuente de virtud y se oponía a los enemigos de la Revolución. ${ }^{67}$

Al no resolverse la dialéctica de la voluntad general, es decir la creación del "hombre nuevo", los enemigos de la revolución iban en aumento, y al mismo compás, el terror. ¿Qué podía hacer el gobierno revolucionario?:

Si el resorte del gobierno popular en la paz es la virtud, el resorte del gobierno revolucionario es a la vez el terror y la virtud: la virtud sin la que el terror es funesto: el terror sin el que la virtud es impotente. El terror no es sino la justicia expeditiva, severa, inflexible; es por lo tanto una emanación de la virtud; es menos un principio particular que una consecuencia del principio general de la democracia aplicada a las más perentorias necesidades de la patria. ${ }^{68}$

La Revolución Francesa, tal y como afirmaba F. Neher, se hun- dió por la lógica política, por el proceso que aspiraba a crear una 
"sociedad libre". El terror era una emanación de la virtud y esta era la manifestación visible de la contradicción nunca resuelta que sustentó la Revolución Francesa al seguir el pensamiento de Rousseau, la Voluntad General. Si ahora volvemos a Hannah Arendt en sus reflexiones sobre la violencia, veremos que al final su tesis es la misma que la de Feher. Arendt no es una acérrima pacifista, pero es muy consciente de que a la hora de reflexionar sobre la violencia hay que proceder con mucha cautela:

La verdadera sustancia de la acción violenta es regida por la categoría medios-fin cuya principal característica, aplicada a los asuntos humanos, ha sido siempre la de que el fin está siempre en peligro de verse superada por los medios a los que justifica y que son necesarios para alcanzarlo. ${ }^{69}$

Pero es justamente esta sustancia de la acción violenta la que se incrustó en la lógica política de la Revolución Francesa, pues esa sociedad virtuosa a la que aspiraban los jacobinos nunca se concretó; al contrario, los revolucionarios detectaban cada vez más enemigos y el terror alcanzaba paulatinamente cotas cada vez más elevadas. Y no podía ser de otra manera, porque otra idea que compartían también los revolucionarios era, con los matices apuntados, la del progreso que, en el caso que nos ocupa, era la de perfectibilidad. Para Arendt, esta creencia es irracional pues se confunde el progreso de las ciencias naturales con el progreso de la Humanidad, y no solamente no coinciden sino que el progreso del saber puede destruir todo aquello que lo hizo valioso. ${ }^{70}$

Arendt establece una distinción muy fértil entre violencia y poder, porque donde este se ha desintegrado, la revolución - aunque no necesariamente- se vuelve posible. Poder es la capacidad humana para actuar concertadamente, nunca es propiedad de un individuo, pertenece a un grupo y sigue existiendo mientras el grupo permanece unido. ${ }^{71}$ Lo que le distingue de la violencia es el carácter instrumental de esta, y por eso puede ser justificable, pero nunca legítima:

El quid está en que, bajo ciertas circunstancias, la violencia - actuando sin argumentación ni palabras y sin consideración a las consecuencias - es el único medio de restablecer el equilibrio de la balanza de la justicia. En este sentido, la rabia y la violencia, que a veces - no siempre-le acompaña figuran entre las emociones humanas "naturales", y curar de ellas al hombre no sería más que deshumanizarle y castrarle. ${ }^{72}$ 
Arendt, pues, no es una defensora absoluta de la no violencia, apuesta por la violencia en ciertas circunstancias, pero nos advierte de algo que no podemos perder de vista:

\begin{abstract}
Si los fines no se obtienen rápidamente, el resultado no será solo una derrota sino la introducción de la práctica de la violencia en todo el cuerpo político. La acción es irreversible y siempre resulta improbable en caso de derrota una vuelta al statu quo. La práctica de la violencia, como toda acción, cambia el mundo, pero el cambio más probable originará un mundo más violento. ${ }^{73}$
\end{abstract}

Esto es precisamente lo que le ocurrió a la Revolución Francesa. Fue tal el peso de las contradicciones iniciales, de la contradicción central, que la violencia, como medio, como instrumento, no solo se vio impotente para abrir un espa- cio liberador, sino que terminó por incrustarse en el cuerpo político, es decir, arruinó cualquier manifestación de poder, de libertad, de pluralidad. Arendt nos recuerda un lugar común que debe ser tenido en cuenta:

Quizá sea un lugar común afirmar que liberación y libertad no son la misma cosa, que la liberación es posiblemente la condición de la libertad, pero que de ningún modo conduce directamente a ella; que la idea de libertad implícita en la liberación solo puede ser negativa y, por tanto, que la intención de liberar no coincide con el deseo de libertad. ${ }^{74}$

Una revuelta contra el ocupante extranjero o contra una sociedad de privilegios, como la francesa, no garantiza la libertad, puede ser una condición necesaria pero no suficiente. Luis Villoro, en un excelente artículo - "Poder, contrapoder y violencia"75-, abunda en las meditaciones de Arendt y puede aportar más luz en este asunto. El autor comienza distinguiendo entre un poder impositivo y otro expositivo o contrapoder. El primero domina, coacciona e impone; como su fin es obstruir acciones ajenas para sustituirlas por las propias, se ve abocado al uso de la violencia. El segundo no aspira a dominar, sino a no ser dominado, quiere actuar por sí mismo determinado por su propia voluntad. A la violencia le opone una no-violencia activa y su ámbito es el de la comunicación. Pero concluye como Arendt:

Si ha de ser fiel a sí mismo, el contrapoder no puede reemplazar un poder por otro, ni oponer una a otra violencia. 
Sin embargo, ante la fuerza del poder, a menudo mina sus actos. De resistencia contra el poder en nombre de un valor, se transforma en un poder impositivo más. Entonces se niega a sí mismo y deja libre el curso del círculo de la violencia. ${ }^{76}$

Una vez más nos encontramos con la lógica política de la Revolución Francesa, una tiranía sustituye a otra, lo que ocurre, como dice
Villoro, cuando el pueblo se convierte en masa. También esto era denunciado por Arendt al presentar los sistemas totalitarios:

La masa no es el pueblo. El pueblo está constituido por un conjunto de personas ligadas en una red de relaciones sociales; la masa es un cuerpo indiferenciado, anónimo, en el que se confunden las personas. (...) La masa, puesto que se cree pueblo, empieza también exponiendo un valor común frente a los poderes existentes, pero necesita personificar un "enemigo del pueblo" a quien imponer su poder. Es el "traidor", el "renegado", el "enemigo de clase", el "Satán". ${ }^{77}$

En la misma línea de reflexión, podemos recordar la sutil distinción benjaminiana entre la violencia mítica y la violencia divina. Los revolucionarios entendían la violencia mítica en forma de un derecho im- positivo, un derecho que generaba violencia y la mantenía. ¿Cómo superar esta situación? Leamos el artículo de Reyes Mate, "Por una moratoria en el uso de la violencia revolucionaria":

La pregunta es si están dispuestos a pasar de la violencia mítica a la violencia divina, es decir, a esa forma de violencia del no matarás que al tiempo que denuncia toda suerte de negación del otro, se hace violencia a sí misma para neutralizar toda pretensión de dominio. ${ }^{78}$

Sabemos que los jacobinos no solo no consiguieron pasar de una a otra, sino que desde "el terror virtuoso", desde el inicio de la Revolución, la violencia mítica fue la protagonista y alcanzó niveles elevadísimos, como no podía ser de otra manera, por la lógica política presente en los acontecimientos. Leamos ahora la definición de "revolución" de Arendt:

Solo podemos hablar de revolución cuando está presente este "pathos" de la novedad y cuando ésta aparece asocia- 
da a la idea de la libertad. Ello significa, por supuesto, que las revoluciones son más que insurrecciones victoriosas y que no podemos llamar a cualquier golpe de Estado revolución, ni identificar a ésta con toda guerra civil. ${ }^{79}$

Si admitimos esta definición de "revolución", ¿caben la Americana y la Francesa en este rubro? En mi opinión, no, porque: ¿qué entiende Arendt por novedad? Supongamos que se hubiesen consumado, ien qué desembocarían una y otra? La Francesa, en una sociedad de clases; la Americana obtendría una ansiada libertad asentada en la esclavitud, pues la cuestión social no entra en el espacio político o público. En ambos casos, nos encontramos con sociedades jerarquizadas en las que no todos los ciudadanos pueden participar por igual en los asuntos públicos, y deben ser todos. Para Arendt no hay ningún saber "objetivo" en materia política, no hay "expertos", no hay "filósofos reyes", la política es asunto de todos los ciudadanos, pues, en principio, son capaces de pensar y juzgar. Como bien apunta Paolo Flores D’Arcais:

La idea de un saber "objetivo" en la esfera política contiene ya en sí la atribución de todo el poder a un monócrata que posea las llaves de la dialéctica histórica, o que en otro sentido sea el elegido del señor. Y que, por lo tanto, reprima el múltiple y libre hacer político de los individuos. ${ }^{80}$

Más adelante, Arendt insiste en el valor instrumental de la violencia, ya que si hubiera instituciones que impiden u obstruyen "éste múltiple y libre hacer político de los individuos", aquella es un medio necesario que debe ser utilizado con cautela. Y matiza una vez más:

Pero ni la violencia ni el cambio pueden servir para descubrir el fenómeno de la revolución; solo cuando el cambio se produce en el sentido de un nuevo origen, cuando la violencia es utilizada para constituir una forma completamente diferente de gobierno, para dar lugar a la formación de un cuerpo político nuevo, cuando a la liberación de la opresión conduce, al menos, a la constitución de la libertad, solo entonces podemos hablar de revolución. ${ }^{81}$

Hasta aquí, la violencia. Pero veamos cuál es su origen. En estas líneas encontramos una primera muestra de la contradicción antes apuntada: 
Desde una perspectiva histórica, la diferencia más notoria y decisiva entre las revoluciones francesa y americana reside en que la herencia histórica de la Revolución Americana era "la monarquía limitada", en tanto que la de la Revolución Francesa era un absolutismo que aparentemente hundía sus raíces en los primeros siglos de nuestra era y en los últimos del Imperio romano. Es perfectamente natural que una revolución esté predeterminada por el tipo de gobierno que viene a derrocar; nada por tanto tan plausible como explicar el nuevo principio absoluto, la revolución absoluta, en función de la monarquía absoluta que le precedió y llegar así a la conclusión de que cuanto más absoluto sea el gobierno más absoluta será la revolución que le reemplaza. ${ }^{82}$

Arendt afirma -la negrita es mía- que una revolución está predeterminada por el gobierno que derroca. Pues bien, si ahí se encuentra la diferencia entre ambas revoluciones, ¿por qué insistir en lo social? En el mejor de los casos, siguiendo su tesis, lo social aceleraría el fin de la francesa, pero nada más. Es la diferente lógica política, como apuntaba Feher, que siguieron según las ideas que les proporcionaban su respectiva legitimidad: las de Rousseau, en un caso; las de Montesquieu, en otro. Pero sigamos leyendo con atención, porque en las siguientes líneas Arendt aclara lo anterior:

Puesto que la persona del rey había sido no solo la fuente de todo poder secular, sino que su voluntad era el origen de todas las leyes positivas, la voluntad de la nación tenía que ser evidentemente, a partir de ahora, el Derecho mismo. Sobre este punto, los hombres de la Revolución Francesa estaban tan de acuerdo como los hombres de la Revolución Americana lo estaban sobre la necesidad de limitar el gobierno; del mismo modo que la separación de poderes de Montesquieu se había convertido en un axioma para el pensamiento político americano, también la idea de una Voluntad General de Rousseau que inspiraba y dirigía a la nación, como si ésta formase una persona y no estuviera compuesta de una multitud, llegó a constituir un axioma para todos los partidos y facciones de la Revolución Francesa, porque era un sustitutivo teórico de la voluntad soberana del monarca absoluto. ${ }^{83}$ 
Fue, entonces, la Voluntad General la premisa de la Revolución Francesa y su ruina. La voluntad no sale bien parada en el pensamiento arendtiano, ya que por definición es una e indivisible, y por ello excluye el consentimiento, la confrontación de opiniones y de puntos de vista; en resumen, excluye la pluralidad, axioma de la acción política. La idea de "masificación" de Villoro está en la mente de Arendt, la supresión de ese espacio entre homogeneiza a los seres humanos al anular sus diferencias. Además, el contrato social, base de la Voluntad General, era una institución que ocultaba un nuevo absolutismo, solo que ahora el "nuevo monarca" sería el pueblo, de ahí que Arendt introduzca la siguiente distinción:

El contrato mutuo mediante el cual los individuos se vinculan a fin de formar una comunidad se basa en la reciprocidad y presupone la igualdad; su contenido real es una promesa y su resultado es ciertamente una "sociedad" o "coasociación", en el antiguo sentido romano de societas, que quiere decir alianza. (...) De otro lado, en el llamado contrato social suscrito entre una determinada sociedad y su gobernante, estamos ante un acto ficticio y originario de cada miembro, en virtud del cual entrega su fuerza y poder aislados para constituir un gobierno; lejos de tener un nuevo poder, mayor eventualmente del que poseía, cede su poder real y lejos de vincularse mediante promesas, se limita a manifestar su "consentimiento" a ser gobernado por el gobierno, cuyo poder se compone de la suma de total de fuerzas que todos los individuos le han entregado y que son monopolizadas por el gobierno para el supuesto beneficio de todos los súbditos. ${ }^{84}$

Rousseau siempre defendió que mediante el contrato social, aunque cada quien se asociara con otros, siempre se obedecía a sí mismo y no perdía la libertad que ya disfrutaba. Arendt no comparte el optimismo del ginebrino y ve un nuevo absolutismo.

De este fundamento viciado no podía salir nunca una cons- titución que abriese un espacio político consistente y duradero. Si a esto le añadimos que el proceso revolucionario se dilataba y que la presencia de la violencia por ello se acrecentaba, la Revolución Francesa tenía sus días contados. Para Arendt, el gran olvidado en Francia fue Montesquieu, defensor de la separación de poderes, no así en América: 
Los redactores de las constituciones americanas, aunque sabían que tenían que establecer una fuente del Derecho y proyectar un nuevo sistema de poder, nunca se sintieron tentados de hacer derivar Derecho y poder de un origen común. Para ellos el asiento del poder se encontraba en el pueblo, pero la fuente del Derecho iba a ser la Constitución, un documento escrito, una entidad objetiva y duradera que, sin duda, podía concebirse de mil modos distintos e interpretarse de formas muy diversas y que podía cambiarse y reformarse de acuerdo a las circunstancias, pero que, sin embargo, nunca fue concebida como un estado de ánimo, como la voluntad. ${ }^{85}$

El reinado del terror que se instaló en Francia fue la lógica consecuencia de un vacío de poder -en el sentido arendtiano- que los revolucionarios no consiguieron llenar. La ruina de la Revolución no fue "la cuestión social", la lógica revolucionaria impuso una rígida "moral" desde el inicio que solo pudo ser conservada por el "terror virtuoso". La Voluntad General impuesta por los jacobinos impidió la acción política, la única verdadera para Arendt, al imposibilitar la pluralidad de actores:

La gramática de la acción: la acción es la sola facultad humana que exige una pluralidad de hombres; la sintaxis del poder: el poder es el único atributo humano que se da en el espacio secular interhumano gracias al cual los hombres se ponen en relación mutua, se combinan en el acto de fundación en virtud de la prestación y cumplimiento de las promesas, las cuales, en la esfera de la política, quizá constituyen la facultad humana superior. ${ }^{86}$

\section{V- La cuestión social}

He intentado mostrar en las líneas anteriores que Arendt se contradijo al analizar las causas del fracaso de la Revolución Francesa, porque primero reconoce una lógica política errada desde el inicio —incrustada en la ideo- logía jacobina- y luego carga todas las tintas en la injerencia de la cuestión social en la política. ¿Puede desentenderse la política del ámbito social? Sigamos sus razonamientos en este resbaladizo y espinoso asunto: 
No sería justo considerar natural el éxito de la Revolución Americana y enjuiciar severamente el fracaso de los hombres de la Revolución Francesa. El éxito no se debió simplemente a la sabiduría de los fundadores de la república, aunque, por supuesto fueron hombres de gran sabiduría. No debe olvidarse que la Revolución Americana, aunque triunfó, no acertó a establecer el novus ordum saeculorum que aunque estableció "de hecho" la Constitución, "dándola una existencia real... en una forma visible", sin embargo no llegó a ser "con respecto a la libertad, lo que la gramática es con respecto al lenguaje. Éxito y fracaso se explican porque no existía en la escena americana, a diferencia de lo que ocurría en los restantes países del mundo, la pobreza. Se trata de una afirmación absoluta que requiere una doble explicación. ${ }^{87}$

En la primera explicación, Arendt distingue pobreza, miseria e indigencia. Los hombres industriosos en Norteamérica eran pobres mas no indigentes, de ahí que se planteara un problema político (qué forma de gobierno adoptar) y nunca social (cómo ordenar la sociedad). La segunda explicación tiene que ver con la entrada en escena de la compasión, sentimiento que opera siempre al margen de la política; más todavía, es impolítica por excelencia:

Desde entonces la pasión de la compasión ha obsesionado e inspirado a los mejores hombres de todas las revoluciones, siendo la americana la única revolución donde la compasión no desempeñó papel alguno en la motivación interna de sus autores. ${ }^{88}$

Dejaré el tema de la compasión para el final y ahora me centraré en la cuestión social. Arendt parte de la existencia de dos mundos, el privado y el público, autónomos, independientes, siendo el segundo en el que realmente somos seres humanos porque en el primero tan solo nos preocupamos de las necesidades vitales, de supervivencia, lo que nos "emparenta" con los animales. En el segundo, el públi- co, vivimos en la política, actividad estrictamente humana, espacio en el que nos reconocemos como seres libres, iguales, únicos, irrepetibles. Mientras que el primero está regido por la razón instrumental, mediosfines, en el segundo actuamos conjuntamente, manteniendo ese espacio entre, sin finalidad; cada acción es siempre nueva y no conocemos las consecuencias que se van a derivar. En el mundo privado, 
el actor no goza de libertad ni de visibilidad, pues la única que tiene el actor en el mundo privado es la del mercado, y en este la pregunta no es ¿quién eres?, sino ¿qué eres? Para Arendt, el fin de la política comienza cuando estos mundos se imbrican, se "confunden". Y esto es, a juicio de Arendt, lo que causó la ruina de la Revolución Francesa, porque la política se hizo cargo de la miseria, esto es, la cuestión social, el mundo privado, el mundo de la supervivencia penetró en el espacio público.
Que no debemos confundir el ámbito público con el privado es el primer paso para que la política esté saneada y así los intereses privados se diferencian de los públicos. Pudiérase entender que Hannah Arendt esté denunciando la ruina de lo político al observar la actuación del Estado de bienestar en las sociedades del primer mundo: la creciente despolitización y la conversión del Estado en una gran empresa oferente de bienes y servicios a cambio de impuestos. Pero Arendt va más allá. Leamos:

De aquí el malestar que siente el pobre, una vez que siente asegurada su propia conservación, consiste en vivir una vida sin sentido y en permanecer fuera de la luz que irradia de la esfera pública, donde puede descollar la excelencia; permanece a oscuras donde quiera que vaya. ${ }^{89}$

¿Es este realmente el comportamiento del pobre una vez liberado de la necesidad? ¿No es esta la teoría aristotélica de la esclavitud?: "Hay hombres que son esclavos por naturaleza". Arendt no puede desprenderse del servil homo laborans
- figura que analiza en La condición humana ${ }^{90}$-, el hombre que está esclavizado por la necesidad y servidumbre inherentes a la vida humana. Si esta es la condición inmutable de la mayoría, la conclusión se desprende de inmediato:

Era innegable que la liberación de la tiranía significó libertad solo para unos pocos y apenas nada para la mayoría, que siguió abrumada por la miseria. Tenían que ser liberados una vez más y, comparada con esta liberación del yugo de la necesidad, la primitiva liberación de la tiranía debió parecer un juego de niños. ${ }^{91}$

Pero entonces la política nunca será lo que Arendt propone; es más, volvemos a la polis antigua donde solo los libres podían dedicarse a los asuntos públicos. Y no se entienda por libre lo contrario de esclavo: libre es aquél que "tenía tiempo libre"; el trabajador "libre" no lo tenía, debía dedicarse a su trabajo. Así, la acción política será 
un privilegio de una excelsa minoría que no trabaja con su cuerpo y que ve cubiertas sus necesidades, pues son otros los que le proporcionan los medios de vida. Estamos ante una visión aristocrática, elitista de la política, que arruina lo mejor del pensamiento aredntiano y lo desmiente:

La Revolución americana se dirigía a la fundación de la libertad y al establecimiento de instituciones duraderas, y a quienes actuaban en esta dirección no les estaba permitido nada que rebasase el marco del Derecho. La Revolución francesa se apartó, casi desde su origen, del rumbo de la fundación a causa de la proximidad del padecimiento; estuvo determinada por las exigencias de la liberación de la necesidad, no de la tiranía, y fue impulsada por la inmensidad sin límites de la miseria del pueblo y de la piedad que inspiraba esta miseria. La anarquía que representaba el principio "todo está permitido" en este caso todavía procedía de los sentimientos del corazón, cuya inmensidad contribuyó a la liberación de una corriente de violencia sin límites. ${ }^{92}$

Lo que no nos dice Arendt es quiénes iban a ser esos hombres que iban a disfrutar de la libertad, porque si algo llama poderosamente la atención del pensamiento arend- tiano es su insensibilidad ante una institución como la esclavitud. Estoy completamente de acuerdo con Martin Jay cuando escribe:

La insensibilidad de Hannah Arendt en esta cuestión se percibe en toda su perversidad en su observación de que el hecho de que la Revolución americana no afrontara la cuestión de la esclavitud fue una de las claves de su "éxito", cuando está claro que desde entonces dicho "éxito" ha sido socavado por su misma omisión. ${ }^{93}$

Todo este razonamiento arendtiano alrededor de la cuestión social está fundado en una confusión que le impide pensar realmente lo político: lo político nunca desaparece, otra cosa es cómo se concrete. Erradicar la miseria, devolver la dignidad humana a una población a la que no se le reconoce, es una decisión política. Qué medidas sean precisas puede ser una decisión técnica, pero en el origen siempre hay una decisión política. Un programa de viviendas dignas para la población parte de una decisión política que no acepta la miseria como opción y que no todo gobierno lo cree necesario; cómo se implemente será una 
cuestión técnica: financiación, coste de materiales, diseño, ubicación, etc. En una discusión que mantuvo en Toronto con colegas y amigos, R.
Bernstein le preguntaba si podía desvincularse o separarse lo social de lo político sin caer en contradicciones. Esta fue la respuesta de Arendt:

Creo que sí. Hay asuntos en que es posible calcular las medidas adecuadas. Se trata de asuntos que pueden efectivamente resolverse por vía administrativa y que, con ello, dejan de ser objeto de debate público. El debate público solo puede abordar asuntos que, para decirlo de manera negativa, no admiten un cálculo seguro. Por lo demás, si es posible calcular con seguridad las medidas que deben tomarse, ¿por qué tenemos que reunirnos? ${ }^{94}$

En esa misma discusión, Mary McCarthy le pregunta qué cabía hacer en la escena pública, en el espacio público, si no era ocuparse de los problemas sociales. Si que- dan excluidas de la escena política todas las cuestiones relacionadas con la economía o el bienestar, el asunto resulta misterioso:

Lo único que queda son las guerras y los discursos. Pero los discursos no pueden ser meros discursos. Deben ser discursos sobre algo. ${ }^{95}$

Arendt concibe la política de forma tan pulcra, tan inmaculada, que no la quiere mezclar con nada, cualquier cálculo utilitarista es desechado en su totalidad. La política no tiene ninguna finalidad más que la política misma, y ver lo contrario sería, para Arendt, ensuciarla, porque se identificaría la acción política con la acción instrumental, es decir: en la política tendrían cabida los técnicos, los expertos, cosa que no puede ser, porque la política es de todos, y aquí no hay sabios ni ignorantes. En la política se vierten opiniones, no enunciados "científicos". Y este es, para mí, el error de Arendt: las decisiones políticas y técnicas o instrumentales tienen su propio espacio, son autónomas, pero nunca independientes. Por esto le recordaba Mary McCarthy que los discursos deben ser discursos sobre algo si no quieren ser vacíos, y el misterio está en que en las muchas páginas que dedica Arendt a la política no se encuentra nada relativo a ese algo. $Y$ esto es muy grave, porque entonces la política parece ser cosa de una élite que se dedica a hablar por hablar completamente ajena al entorno que le rodea. $Y$ de aquí volvemos a la acusación de insensibilidad del pensamiento arendtiano motivada por esa concepción tan particular. En palabras de Martin Jay: 
Al situar la igualdad y la libertad en el ámbito político, condenó por definición la esfera de lo no político a la desigualdad y a la opresión eternas. Tal como ella misma reconoce, la polis, su prototipo favorito de comunidad política, fue propiciada por la institución de la esclavitud, que liberó a los ciudadanos atenienses de pleno derecho de las tareas domésticas, gobernadas por la pura necesidad. En el mundo moderno, donde la esclavitud es más difícilmente justificable, la propiedad privada es el sine qua non de la participación política. ${ }^{96}$

Si se aceptan las premisas arendtianas, la conclusión es irrefutable: la compasión que causa la miseria es nefasta porque es una emoción, un sentimiento contaminador de la política. Pero, iy si fuera una virtud política?

\section{VI- La compasión, ¿emoción o virtud?}

J. Habermas recuerda su último encuentro con un Herbert Marcuse agonizante:

En esta ocasión, que fue en verdad nuestro último encuentro filosófico, Marcuse, conectando con nuestra discusión de dos años antes, me dijo: "¿Ves? ahora sé en qué se fundan nuestros juicios valorativos más elementales: en la compasión, en nuestro sentimiento por el dolor de los otros" ${ }^{97}$

Volvamos a H. Arendt y a su esta arremete sin piedad contra la obra Sobre la revolución, porque en compasión:

La Revolución americana se dirigía a la fundación de la libertad y al establecimiento de instituciones duraderas, y a quienes actuaban en esta dirección no les estaba permitido nada que rebasase el marco del Derecho. La Revolución francesa se apartó, casi desde su origen, del rumbo de la fundación a causa de la proximidad del padecimiento; estuvo determinada por las exigencias de la liberación de la necesidad, no de la tiranía, y fue impulsada por la inmensidad sin límites de la miseria del pueblo y de la piedad que inspiraba esta miseria. La anarquía que representaba el principio "todo está permitido" en este caso todavía procedía de los 
sentimientos del corazón, cuya inmensidad contribuyó a la liberación de una corriente de violencia sin límites. ${ }^{98}$

La compasión es para Hannah Arendt la gran lacra de la Revolución Francesa hasta el punto de ser la causante de la instalación de ese terror virtuoso que llevó a la guillotina a tantos "enemigos". Pero, ipor qué es tan nociva la compasión? Porque es absolutamente impolítica:

La magia de la compasión consistía en que abría el corazón del que padece a los sufrimientos de los demás, por lo que establecía y confirmaba el vínculo "natural" entre los hombres que solo los ricos habían perdido. Donde terminaban la pasión (la capacidad para el padecimiento) y la compasión (la capacidad de padecer con los demás) comenzaba el vicio. ${ }^{99}$

Es ese vínculo "natural" que establece la compasión, el enemigo a batir porque elimina ese espacio entre que se da en la vida política. La acción política es siempre el comienzo de algo nuevo, y se manifiesta con la reunión de seres humanos, todos iguales, todos diferentes, que ven y se dejan ver, que hablan y que escuchan, que opinan, y para eso es preciso que haya una distancia entre ellos. Si el totalitarismo atomiza a los hombres cortando cualquier relación entre ellos, la compasión los masifica al disolver la distancia que siempre debe mantenerse en el espacio público:

El pecado del Gran Inquisidor fue que, como Robespierre, "se sentía atraído por les hommes faibles, no solo porque dicha atracción era inseparable de su ansia de poder, sino también porque había despersonalizado a los sufrientes, juntando a todos ellos en un conglomerado informe: el pueblo toujours malheureux, las masas sufrientes, etc... ${ }^{100}$

Según Arendt, la compasión no puede ser movida por los padecimientos de una clase o un pueblo, menos aún por los de la humanidad. No va más allá de del padecimiento de una persona, de ahí el vocablo co-padecimiento. Si la acción política siempre es artificial, cualquier vínculo "natural" la arruinará:

La compasión, y en este sentido se asemeja al amor, anula la distancia, el espacio que siempre existe en las relaciones humanas. ${ }^{101}$ 
Arendt va más lejos en su razonamiento, porque si la compasión es un sentimiento impolítico, abrirá las puertas de la violencia, de ahí la instalación del "terror virtuoso" en el seno de la Revolución, porque donde termina la política empieza la violencia. Esta puede remover obstáculos para abrir un nuevo espacio público, pero no puede perpetuarse:

En general, la compasión no se propone transformar las condiciones del mundo a fin de aliviar el sufrimiento humano, pero, si lo hace, evitará el largo y fatigoso proceso de persuasión, negociación y compromiso en que consiste el procedimiento legal y político y prestará su voz al propio ser que sufre que debe reivindicar una acción expeditiva y directa, esto es, una acción con los instrumentos de la violencia. ${ }^{102}$

Esta exposición de H. Arendt quedaría incompleta si aquí pusiésemos el punto final en lo relativo a la compasión, porque la autora cree poder dar una salida a tan espinoso asunto. Tiene muy claro que la piedad es la perversión de la compasión, y cree ver en la "solidaridad" la solución:

Es la piedad la que "empuja a los hombres hacia les hommes faibles", pero es gracias a la solidaridad como ellos fundan deliberadamente y, si así puede decirse, desapasionadamente una comunidad de intereses con los oprimidos y explotados. El interés común podría ser "la grandeza del hombre", "el honor de la raza humana" o "la dignidad del hombre. ${ }^{103}$

Debo reconocer que no entiendo este párrafo, en especial la conjunción de solidaridad y ausencia de pasión. "Solidaridad" es un vocablo que tiene su origen en el francés "solidarité", y este a su vez en los latinos "solidario" y "solido". Si alguna idea atraviesa las distintas acepciones de "solido" es la de compacidad, el carácter de compacto de algo. Unidad máxima y máxima indistinción de las partes, todo es uno. Si en vez de materiales hablamos del mundo del derecho, se dice de las obligaciones contraídas in solidum y de las personas que las contraen; aunque fue otro el que cometió la acción, la responsabilidad recae también en mí. ¿Dónde está la separación, la distancia entre que borraba la compasión? ¿Dónde quedan "la grandeza del hombre", "el honor de la raza humana" o "la dignidad del hombre" cuando se pasa por alto que una revolución como la americana se afirmara prescindiendo de una institución como la esclavitud? 
¿De qué habla Arendt? La kantiana Arendt confunde la revolución con un simple cambio de estructuras, y esa es la causa, en mi opinión, de su desafección por los oprimidos. Pero volvamos al razonamiento arendtiano cuando sostiene que la compasión tiene lugar en un espacio interpersonal, pero que se dirige a una sola persona: aquella que padece. ¿Es esto cierto?
Reyes Mate nos informa de dos patrones, dos filosofías o modos de pensar la justicia en Occidente. ${ }^{104}$ Una tiene como principio la visión, "como si el pensar fuera una luz que ilumina, con la que se ilumina la realidad gracias a la mirada del sujeto". Priva la especulación sobre la experiencia. Es el modelo de Atenas, es la imposición de la teoría:

No le interesa tanto entretenerse en la compleja realidad cuanto apropiarse de ese núcleo sustancial que es al tiempo la esencia de la cosa y lo que la cosa tiene de inteligible o iluminable. Ese desprecio epistémico a los detalles es el origen de la "frialdad burguesa" que Horkheimer y Adorno no dejaron de fustigar.

Lo inteligible o iluminable es para Arendt su "idea" de la política, la densa realidad, lo "accidental", y

solo resplandecerá la idea si logra huir de la contaminante realidad. El segundo, según Reyes Mate:

El otro modo de pensar va de oído y tiene por modelo la escucha. Pensar es reaccionar a estímulos exteriores, a preguntas e interpelaciones que vienen de fuera de nosotros. Es el modelo Jerusalén. Lo importante es el otro; lo que tiene valor estructural es la alteridad ya que nos constituimos gracias a la llamada del otro. A ese movimiento que viene del otro y gracias al cual nos constituimos no solo en sujetos morales, sino en sujetos sin más, lo llamamos compasión.

Pudiera parecer que no salimos del "sentimentalismo" que esconde la compasión, pero no es así. Horkheimer destaca tres características de la filosofía moral occidental: deontologismo, universalismo y racionalismo, y en ellas detecta el peligro de todo idealismo: considerar racional la ética que se puede fundamentar racionalmente. ¿Puede una ética fundarse sin apelar a la experiencia? ¿Puede una ética fundarse sin apelar a la rebeldía, la compasión, el amor o la solidaridad? Horkheimer es un pensador que, como Arendt, tuvo que pensar después de Auschwitz, y sin embargo se aleja del pensamiento "oficial". Al igual que Marcuse, Horkheimer afirma que 
es la experiencia del sufrimiento la que nos acerca al otro, un "otro" que no se resigna con su suerte $y$ que pugna por ser feliz. Adorno, por su parte, no ve la verdad sino en el sufrimiento. Pero hay algo más que Arendt ignora, y este es el núcleo de la compasión. Leamos de nuevo a Reyes Mate:

La compasión es, en efecto, un sentimiento y como tal, algo particular y material. Pero es un sentimiento mediado racionalmente: el otro es digno de compasión, no es un mero objeto doliente, sino un sujeto con su dignidad herida, ultrajada o frustrada. Se le reconoce la dignidad de fin y no se le utiliza como un medio, como quería Kant. Esa dignidad con que se nos revela el otro es la dignidad que exige el hombre, la especie humana. Por eso la compasión es la mediación sensible o naturalizada entre lo particular del sentimiento y lo universal de la dignidad humana. ${ }^{105}$

Claro que esta ética compasiva parte de una premisa inconcebible en el pensamiento occidental: la asimetría. Esa dignidad que tiene el otro, realmente no la tiene; si la tiene es como exigencia, lo que tiene es el ultraje. Tratarlo como si ya la tuviera sería dejarlo, abandonarlo a su desgracia, mientras que el yo que con el otro se relaciona podría vivir en su placidez ética. De ahí que la compasión sea el nombre de una ética intersubjetiva, pero no simétrica, sino de acuerdo con la asimetría real:

Hacer depender la universalidad de la asimetría es plantar cara a un modo de pensar hondamente arraigado en la mentalidad occidental. Lo universal pertenece a la familia de la reconciliación, el consenso, lo originario o lo natural, mientras que lo asimétrico es lo particular, diferente y problemático. ${ }^{106}$

Pero, ¿qué ocurre con la política? ¿Es posible hablar de una política compasiva?:

La compasión obliga al que se compadece a remover los obstáculos que impiden al otro tener la dignidad. Esa actitud activa es la política. ${ }^{107}$

Esto solo se puede lograr mediante políticas de integración, es decir, mediante políticas sociales, políticas que se hagan cargo de las 
injusticias del presente y del pasado, políticas anamnéticas, políticas "materiales", no simplemente procedimentales, políticas que luchan contra cualquier marginación, en resumen, políticas que parten de la asimetría. Y es este punto de partida el eterno ausente en la obra de Arendt.

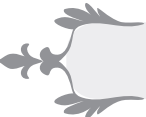

\section{Conclusiones}

Presentaba a Hannah Arendt en la introducción como una pensadora polémica, independiente y muy ideosincrática. El siglo XX no será el "siglo de Hannah Arendt", como pretenden sus "defensores", pero tampoco el de su "defenestración", si se me permite decirlo así, como afirman sus detractores.

A Hannah Arendt habrá que seguir leyéndola porque, como ella misma afirmaba, "todo lo que he hecho y todo lo que he escrito es provisional". Y esto es de agradecer, porque más allá de que se esté de acuerdo o no con sus ideas, Arendt no solamente se alejó de aquellos autores que pretenden sentar cátedra o dar por zanjados temas, sino que nos animó a pensar, a pensar "sin barandillas". Y muy cartesianamente defiende que tenemos que pensar como si nadie nunca hubiera pensado, que solo después es el momento de aprender de los demás. ¿No decía Husserl que todo filósofo que merezca este calificativo debe comenzar de cero alguna vez en su vida? Arendt nos advirtió del peligro de pensar, a la vez que aseguraba que no pensar podía ser más peligroso, y esto lo aprendió de Eichmann. $Y$ es que las respuestas de este criminal nazi le convencieron de que el mal no es radical sino que es banal, que el peligro está tan cerca de nosotros que no lo vemos, que la monstruosidad del siglo XX no fue perpetrada por monstruos, sino por hombres vulgares, incapaces de pensar, fieles cumplidores de órdenes. Las ideas no son peligrosas, el peligro está en el pensar. El pensamiento, que no el conocimiento, vuelve sobre sus propios pasos, una vez en marcha no se detiene nunca, no tiene ninguna finalidad, mucho menos nos promete la felicidad. El pensamiento socava las reglas fijas, las convicciones generales, mostrando su falsedad. Arendt leía con entusiasmo la Crítica del juicio de Kant, y aseguraba que ahí se encontraba la verdadera filosofía política del profesor de Könisberg, y no en la Crítica de la razón práctica. $Y$ es que en aquella se recupera el sano "sentido común", el gusto y, sobre todo, esa capacidad de juzgar ampliada, el juicio reflexionante, "según el cual uno puede juzgar en el lugar de todos los demás". Obsérvese que no se trata de pensar "en lugar de" sino "en el lugar de". Si lo primero lleva a la exclusión, lo segundo asegura la exigencia de comunicabilidad. 
Pero ese vigor intelectual en la obra de Arendt termina por quebrarse en el momento en el que, quizá por salvar la política de las instituciones que la difuminan o simplemente la anulan, termina por situarla más allá del espacio y del tiempo. En otras palabras, la ubica en ese mundo de las ideas que tanto criticó, y esta es la causa de que el tratamiento de las revoluciones sea tan contradictorio. Si toda revolución está predeterminada por el gobierno que suple, no se ve dónde radica su novedad, simplemente cambian los gobernantes sin que desaparezcan los elementos que la provocaron. Al independizar primero la política de cualquier otro ámbito, y al absolutizarla después, la anula; y en ese envite olvida que si la acción política es diferente de la instrumental, autónomas en sus respectivos campos, ambas son dependientes, pues a toda decisión política le sigue otra técnica que

Notas

1 R. Jahanbegloo, I. Berlin en diálogo con Ramin Jahanbegloo, Ed. Anaya.

2 R. Mate, Por los campos de exterminio, Ed. Anthropos.

3 M. Onfray, El sueño de Eichmann, Ed. Gedisa.

4 I. Kant, La religión dentro de los límites de la mera razón, Alianza Editorial, pp. 4647.

5 H. Arendt, Los orígenes del totalitarismo, Ed. Taurus, p. 11. puede afectar al mundo jurídico, económico, etc... Esta incontaminación de la política deriva en un procedimentalismo o formalismo incapaz de formular los problemas reales en sociedades concretas, pues si — por un lado- defiende la política como un espacio abierto a todos los ciudadanos, al desentenderse de los problemas sociales - por otro-, ese espacio solo puede ser ocupado por una elite que terminará por defender intereses privados, nunca públicos. Al faltar en el pensamiento arendtiano cualquier referencia a la justicia $-\mathrm{O}$ a la injusticia- no solo la compasión sale mal parada, sino que cualquier acción política, ese nuevo comienzo, nace viciada al ignorar no solo las demandas de las víctimas del presente, sino también del pasado. En otras palabras, estamos ante un pensamiento anamnético que impide reformular, como ella deseaba, la política después de Auschwitz.

6 Creo interesante recordar que para S. Bauman y W. Benjamin no había nada que comprender, pues la barbarie ya estaba instalada en la misma Modernidad, y el mito del progreso era su mejor manifestación. Así, Benjamin afirmaba que era poco filosófico asombrase por lo que estaba ocurriendo.

7 H. Arendt, ibíd., p. 561.

8 H. Arendt, Eichmann en Jerusalén. Un estudio sobre la banalidad del mal, Ed. Lumen. 
9 La solución final tenía que aplicarse a todos los judíos de Europa, cuyo número se estimaba en once millones.

10 H. Arendt, ibíd., p. 46.

11 Ibíd., p. 55.

12 I. Kant, ¿Qué es la Ilustración?, Alianza Editorial, p. 83.

13 H. Arendt, ibíd., p. 76.

14 Ibíd., p. 80.

15 N. Bilbeny, El idiota moral, Ed. Anagrama, p. 87.

16 H. Arendt, ibíd., p. 192.

17 Ibíd., p. 206.

18 Ibíd., p. 382.

19 H. Arendt, Lo que quiero es comprender, Ed. Trotta, pp. 34-35.

20 F. Birulés (compiladora), Hannah Arendt: el orgullo de pensar, Ed. Gedisa, pp. 235-256.

21 H. Arendt, Lo que quiero es comprender, Ed. Trotta, p. 56.

22 H. Arendt, De la historia a la acción, Ed. Paidós, pp. 109-137.

23 Ibíd., p. 110.

24 Ibíd., p. 114.

25 Ibíd., p. 118.

26 Ibíd., p. 119.

27 Ibíd., p. 120.

28 Ibíd., p. 125.

29 Ibíd., p. 127.

30 Ibíd., p. 130.

31 Ibíd., p. 132.

32 Julio Quesada Martín, La filosofía y el mal, Ed. Síntesis, p. 189.

33 Ibíd., p. 136.
34 Ibíd., p. 137.

35 M. Onfray, El sueño de Eichmann, Ed. Gedisa.

36 Alasdair MacIntyre, Historia de la ética, Ed. Paidós, p. 192.

37 E. Kant, La metafisica de las costumbres, Ed. Tecnos, p. 150.

38 Ibíd., pp. 151-152.

39 E. Kant, Idea de una historia universal en sentido cosmopolita, FCE, pp. 50-51.

40 Ibíd., p. 57.

41 E. Kant, ¿Qué es la Ilustración?, Alianza Editorial, p. 86-87.

42 Ibíd., p. 92.

43 Esplendor y miseria de la ética Kantiana, Ed. Anthropos: "Dignidad y no precio: más allá del economicismo", p. 140-166.

44 Ibíd., p. 166.

45 Ibíd., pp. 167-196.

46 Ibíd., p. 169.

47 E. Kant, Metafísica de las costumbres", Ed. Tecnos, p. 14.

48 M. García Morente, La filosofía de Kant, Ed. Espasa Calpe, p. 143.

49 Esperanza Guisán, Introducción a la ética, Ed. Cátedra, p. 179.

50 Ibíd., p. 180.

51 M. Onfray, ibíd., p. 42.

52 Ibíd., pp. 87-88.

53 Ibíd., p. 89.

54 E. Kant, ¿Qué es la Ilustración?, Alianza Editorial, p. 65.

55 Para más información, véase N. Bobbio, Teoría general del derecho, Ed. Debate, pp. 189-219.

56 Ibíd., p. 225. 
57 E. Kant, Filosofía de la historia, FCE, pp. 105-106.

58 H. Arendt, Sobre la revolución, Alianza Editorial, p. 62.

59 Ferenc Feher, La revolución congelada. Ensayo sobre el jacobinismo, Ed. Siglo XXI, p. 22.

60 Albert Soboul, La Revolución Francesa, Ed. Crítica, pp. 14-15.

61 Ibíd., p. 75.

62 Ibíd., p. 76.

63 Ibíd., p. 76.

64 A. Soubul, ibíd., pp. 50-51.

65 F. Feher, ibíd., p. 76.

66 A. Soubul, ibíd., p. 311.

67 Ibíd., p. 80.

68 A. Soubul, ibíd., p. 339.

69 H. Arendt, Sobre la violencia, ibíd., p. 10.

70 Ibíd., pp. 46-47.

71 Ibíd., p. 60.

72 Ibíd., p. 86.

73 Ibíd., pp. 109-110.

74 H. Arendt, Sobre la revolución, Alianza Editorial, p. 30.

75 A. Sánchez Vázquez (editor), El mundo de la violencia, FCE, pp. 165-175.

76 Ibíd., p. 173.

77 Ibíd.

78 Ibíd., p. 56.

79 H. Arendt, Sobre la revolución, Alianza Editorial, p. 35.

80 P. Flores D'Arcais, Hannah Arendt. Existencia y libertad, Ed. Tecnos.

81 Ibíd. pp. 36-37.
82 Ibíd. pp. 158-159.

83 Ibíd., p. 159.

84 Ibíd., p. 174.

85 Ibíd., p. 160.

86 Ibíd., p. 180

87 Ibíd., p. 69.

88 Ibíd., p. 72.

89 Ibíd., p. 70.

90 H. Arendt, La condición bumana, Ed. Paidós.

91 H. Arendt, Sobre la revolución, p. 75.

92 Ibíd., p. 93.

93 Fina Birulés (comp), H. Arendt. El orgullo de pensar, Ed. Gedisa, p. 165.

$94 \mathrm{H}$. Arendt, Lo que quiero es comprender, Ed. Trotta, p. 81.

95 Ibíd., pp. 79-80.

96 F. Birulés (comp.), H. Arendt, el orgullo de pensar, Ed. Gedisa, p. 163.

97 J. Habermas, Perfiles filosófico-políticos, Ed. Taurus, p. 296.

98 H. Arendt, Sobre la revolución”, p. 93.

99 Ibíd., p. 82.

100 Ibíd., p. 86.

101 Ibíd., p. 87.

102 Ibíd., pp. 87-88.

103 Ibíd., p. 89.

104 Reyes Mate, Tratado de la injusticia, Ed. Anthropos, p. 165.

105 Ibíd., pp. 144-145.

106 Ibíd., p. 145.

107 Ibíd., p. 153. 